\title{
Simulation of the Stable Water Isotopes in Precipitation over South America: Comparing Regional to Global Circulation Models
}

\author{
CHRISTOPHE STURM* \\ Laboratoire de Glaciologie et Géophysique de I'Environnement, CNRS/OSUG, Grenoble, France \\ GeORg HofFMAnN \\ Laboratoire des Sciences du Climate et de I'Environnement, CEA, Saclay, France \\ BÄRBEL LANGMANN \\ Max-Planck-Institut für Meteorologie, MPG, Hamburg, Germany
}

(Manuscript received 26 September 2005, in final form 8 November 2006)

\begin{abstract}
A simulation of the stable water isotope cycle over South America by the regional circulation model $\mathrm{REMO}_{\text {iso }}$ is discussed. The performance of the regional model, with a resolution of $0.5^{\circ}(\sim 55 \mathrm{~km})$, is compared to simulations by the global circulation model $\mathrm{ECHAM}_{\text {iso }}$ at two coarser resolutions and evaluated against observations of precipitation and $\delta^{18} \mathrm{O}$.

Here $\mathrm{REMO}_{\text {iso }}$ is demonstrated to reproduce reasonably well climatic and isotopic features across South America. This paper explores further insights of $\delta^{18} \mathrm{O}$ as a climate proxy, based on $\mathrm{REMO}_{\text {iso }}$ 's improve-

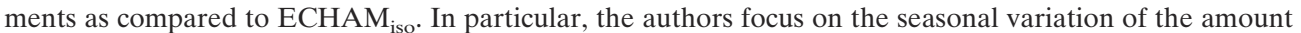
effect $\left(\delta^{18} \mathrm{O}\right.$ decrease with precipitation amounts) and the anomalous $\delta^{18} \mathrm{O}$ continental gradient across the Amazon basin, as inferred from the $\mathrm{REMO}_{\text {iso }}, \mathrm{ECHAM}_{\text {iso }}$, and GNIP datasets. The finer resolution of topography in $\mathrm{REMO}_{\text {iso }}$ enables a detailed analysis of the altitude effect: not only the first, but also the second derivative of $\delta^{18} \mathrm{O}$ with altitude is considered. It appears that high-altitude grid cells show an isotopic signature similar to Rayleigh distillation, in accordance with experimental studies. Finally, a Lagrangian reference frame is adopted to describe the evolution of $\delta^{18} \mathrm{O}$ in precipitation along its trajectory, in order to relate the simulation analysis to the fractionation mechanisms. This confirms that the amount effect, via Rayleigh distillation processes, is dominant during the wet season. During the dry season, the $\delta^{18} \mathrm{O}$ in precipitation is controlled by isotopic reequilibration of rain droplets with surrounding vapor, reflecting the impact of nonfractionating transpiration by the vegetation.
\end{abstract}

\section{Introduction}

Tropical ice cores recovered from several Andean summits represent a unique archive of climate variability in the intertropical belt (Thompson et al. 2000; Ramirez et al. 2003; Ginot et al. 2002). Yet the interpretation of their isotopic signal is more complicated

\footnotetext{
* Current affiliation: Bjerknes Centre for Climate Research, University of Bergen, Bergen, Norway.
}

Corresponding author address: Christophe Sturm, Bjerknes Centre for Climate Research, University of Bergen, Strandgaten 29, NO-5013, Bergen, Norway.

E-mail: kristof.sturm@bjerrknes.uib.no than in the case of polar ice cores. Unlike the latter, precipitation at tropical latitudes is predominantly convective; hence the isotopic signal is less sensitive to local temperature conditions. Further differences include a broader variability in moisture origin, large feedback between vegetation and the hydrological cycle, and local effects caused by the steep surrounding topography.

As a consequence, simple trajectory-based Rayleigh distillation models are not able to account for observed variations in the ice core isotopic composition. Stable water isotope-enabled global circulation models shed a new light on the matter. Recently, Vuille et al. (2003a) conducted a comprehensive study with the ECHAM and the Goddard Institute for Space Studies (GISS) $\mathrm{II}_{\text {iso }}$ GCMs to investigate the climatic controls on the

DOI: 10.1175/JCLI4194.1 
isotopic signal over South America. The authors focus on the interannual, and to a lesser extent the seasonal, variability of the simulated isotopic signal. In a companion article, Vuille et al. (2003b) report that the interannual isotopic signal in tropical Andean ice cores records Pacific sea surface temperature anomalies. Similarly, Bradley et al. (2003) reports that stable water isotope variations in Andean ice cores are primarily related to the El Niño-Southern Oscillation (ENSO) phenomenon.

Furthermore, experimental evidence from an isotopic precipitation sampling network across Bolivia demonstrated that local temperatures have limited influence on the isotopic composition (Vimeux et al. 2005). Back-trajectory analysis shows that, under prevailing intertropical easterlies, the origin of moisture precipitating over eastern Andean summits is located in the Atlantic. Using a centennial simulation by the $\mathrm{ECHAM}_{\text {iso }}$ GCM, Hoffmann et al. (2003) demonstrates that precipitation and recycling by vegetation over the Amazon basin primarily controls the isotopic signal in Andean ice cores. As a further evidence, the isotopic signals in Andean ice cores reveal a high level of similarity, which acknowledges their common moisture origin. Based on the high resemblance, the authors define a common Andean isotope index (AII). Hoffmann (2003) reports that the AII is in good agreement with the first principal component of global precipitation.

Which mechanisms can explain the remote forcing of the tropical Pacific sea surface temperature on the interannual $\delta^{18} \mathrm{O}$ variability, while the moisture originates from the Atlantic? One limitation in the interpretation of the $\delta^{18} \mathrm{O}$ signal might be the coarse resolution of the GCM, which greatly underestimates the Andean topography. For example, at the common T30 resolution, the smoothed Andean orography culminates at $1500 \mathrm{~m}$ MSL (meters above sea level) instead of the actual $6000 \mathrm{~m}$ MSL high peaks and $4000 \mathrm{~m}$ MSL elevated Altiplano. To overcome this limitation, we applied the regional circulation model $\mathrm{REMO}_{\text {iso }}$, fitted with stable water isotope diagnostics, to tropical South America. Hereafter, we focus on the seasonal climate variability across tropical South America, as a first step to analyze the climatic mechanisms controlling the isotopic signal in precipitation.

The present article introduces a 5 -yr simulation by $\mathrm{REMO}_{\text {iso }}$ at a horizontal resolution of $0.5^{\circ}$. The study domain extends from $35^{\circ} \mathrm{S}$ to $15^{\circ} \mathrm{N}, 100^{\circ}$ to $20^{\circ} \mathrm{W}$. We first compare the annual cycle of precipitation simulated by $\mathrm{REMO}_{\text {iso }}$ to ECHAM simulations at T30 $\left(3.75^{\circ} \sim 420 \mathrm{~km}\right)$ and T106 $\left(1.125^{\circ} \sim 125 \mathrm{~km}\right)$ resolutions. Simulated precipitation is evaluated against gridded precipitation observations. We then assess the abil- ity of $\mathrm{REMO}_{\text {iso }}$ to reproduce typical features of the South American atmospheric circulation, such as the Bolivian high and Chaco low. We investigate the benefits of improved resolution for simulation of the stable water isotope signal across South America. The discussion on the simulated isotope signal focuses on the analysis of the simulated altitude effect, as well as the anomalous continental gradient across the Amazon basin. Finally, we adopt a Lagragian reference frame to describe the joint evolution of precipitation and its isotopic signature along the airmass trajectory.

\section{Model and data}

\section{a. Model description and experiment setup}

Two atmospheric circulation models, developed at the Max Planck Institute for Meteorology (Hamburg), were enabled with stable water isotope diagnostics. The global circulation model ECHAM-4 is optimized to run at six spectral resolutions from T21 to T106; we selected two runs at $\mathrm{T} 30\left(3.75^{\circ}, \sim 420 \mathrm{~km}\right.$ at the equator $)$ and $\mathrm{T} 106\left(1.125^{\circ}, \sim 125 \mathrm{~km}\right.$ at the equator) resolution for this study with 19 vertical levels each. Apart from the resolution, the two runs differ by the boundary conditions used to specify the sea surface temperature (SST). The ECHAM T30 run uses the Global Ice and SST (GISST) climatology (Rayner et al. 1996), representing the mean annual SST cycle over the 1979-98 period. After a 3-yr spinup, this T30 simulation covers 10 years, of which the first five were analyzed in the present study. The ECHAM T106 run uses observed, yearly varying SST from 1979 to 1998, of which the five years from 1985 to 1989 were analyzed. The selection of the years 1985 to 1989 are motivated from the analysis of different observational datasets, as described in the next section. Further details about the water isotopeenabled ECHAM model can be found in Hoffmann et al. (1998) and Werner et al. (2000). The regional circulation model $\mathrm{REMO}_{\text {iso }}$, fitted with stable water isotope diagnostics, was run at $0.5^{\circ}(\sim 53 \mathrm{~km})$ resolution with 19 vertical levels. The study domain ranges from $35^{\circ} \mathrm{S}$ to $15^{\circ} \mathrm{N}, 100^{\circ}$ to $20^{\circ} \mathrm{W}$. $\mathrm{REMO}_{\text {iso }}$ was nested into the ECHAM T30 run, mentioned above, with climatological SST conditions. After a 1-yr spinup, the model was integrated over 5 years, corresponding to the five years from the ECHAM T30 run mentioned above. The physical parameterizations and corresponding isotopic fractionation processes were adapted from ECHAM-4. The current version of $\mathrm{REMO}_{\text {iso }}$ (version 5.0-EC4) and its water isotope module is extensively described in Sturm et al. (2005). The major features of the water isotope module are 1) the isotopic tracers $\mathrm{H}_{2}^{18} \mathrm{O}$ and HDO are treated as prognostic variables for both their 
TABLE 1. Specifications of the modeled and observed datasets used in the present article.

\begin{tabular}{|c|c|c|c|c|c|}
\hline Name & Resolution $\left(^{\circ}\right)$ & Source & Period & Total $(\mathrm{mm})$ & Reference \\
\hline \multicolumn{6}{|l|}{ Models } \\
\hline REMO & $0.5 \times 0.5$ & Climatological SST & $5 \mathrm{yr}$ & 2195 & Present paper \\
\hline ЕСНАM Т30 & $3.75 \times 3.75$ & Climatological SST & $5 \mathrm{yr}$ & 1577 & Hoffmann et al. (1998) \\
\hline ECHAM T106 & $1.125 \times 1.125$ & Observed SST & $1985-89$ & 1400 & M. Werner (2006, personal communication) \\
\hline \multicolumn{6}{|l|}{ Observations } \\
\hline WML & $0.5 \times 0.5$ & Gauge on land & $1985-89$ & 1660 & Willmott and Matsuura (2001) \\
\hline GPCP & $2.5 \times 2.5$ & Gauge/satellite & $1985-89$ & 1703 & Huffman and Bolvin (2004) \\
\hline CMAP & $2.5 \times 2.5$ & Gauge/satellite & $1985-89$ & 1630 & Xie and Arkin (2002) \\
\hline CRUtrop & $3.75 \times 2.5$ & Gauge/satellite & $1985-89$ & 1501 & Doherty et al. (1999) \\
\hline CRU & $3.75 \times 2.5$ & Gauge on land & $1985-89$ & 1648 & Hulme et al. (1998) \\
\hline GNIP & 43 stations & Monthly climatology & $1960-2000$ & - & IAEA and WMO (2001) \\
\hline
\end{tabular}

liquid and gaseous phase; 2) the soil module includes three prognostic reservoirs for isotopic tracers, (bucket) soil moisture, canopy interception, and snowpack; 3) evaporation from the sea surface includes both equilibrium and kinetic fractionation depending on wind turbulence (Merlivat and Jouzel 1979); 4) no discrimination is made between evaporation and transpiration from the soil moisture, hence considered nonfractionating; (5) t-phase equilibrium and kinetic effects are accounted for the fractionation in convective and stratiform clouds; and 6) partial reevaporation of rain drops below the cloud induces an isotopic reequilibration with the surrounding moisture, at a rate of $45 \%$ for convective and $95 \%$ for large-scale rain.

\section{b. Gridded precipitation observations and isotopic measurements}

Several gridded precipitation datasets are available, differing in the observational sources and the spatial and temporal resolution.

Here we selected five gridded annual series of monthly precipitation covering the study domain, summarized in Table 1. All datasets cover a 20-yr period from 1979 to 1998, corresponding to the ECHAM T106 experiment, apart from Doherty et al. (1999) which spans 1975 to 1994 . In that period, we identified a period of five consecutive years that deviated the least from the 20-yr mean over the study domain. The use of climatological SST in REMO $_{\text {iso }} /$ ECHAM T30 improves the climatological representativeness of precipitation over a short ( $5 \mathrm{yr})$ integration period.

For each dataset, the mean precipitation over 1985 to 1989 was less than $5 \%$ wetter than the 20 -yr average, apart from the Climate Research Unit (CRU) dataset (9.6\%). Moreover, no extreme anomaly occurred, as the 1986-87 El Niño did not affect precipitation over South America as drastically as the 1982-83, 1992-93, or 1997-98 events. Hence, the period from January
1985 to December 1989 is considered to be representative of the late-twentieth-century conditions over the study domain.

Geopotential heights at $850 \mathrm{hPa}$ were retrieved from the 40-yr European Centre Medium-Range Weather Forecasts (ECMWF) Re-Analysis (ERA-40) data server (ECMWF 2003). As for the precipitation datasets, the selected period runs over $5 \mathrm{yr}$, from January 1985 to December 1989, with a horizontal resolution of $2.5^{\circ}$. The reanalysis project, completed in 2004, assimilates remote-sensed measurements from seven satellites as well as numerous radiosonde and station meteorological data.

Evaluation of modeled isotopic precipitation over South America is complicated because of sparse station measurements in the global network for isotopes in precipitation (GNIP). To maximize the number of stations, we compare model results to the GNIP climatology (IAEA and WMO 2001). A mean annual cycle is constructed for all GNIP stations that were in operation at least three years, between 1961 and 2001. The $\delta^{18} \mathrm{O}$ climatology in the GNIP dataset covers up to 40 years. We considered it more relevant to maximize the spatial coverage rather than to restrict the climatology to stations operating between 1985 and 1989.

\section{Evaluation against observations}

\section{a. Precipitation}

Figure 1 shows the mean annual cycle of precipitation for both models and observations, as listed in Table 1 . The spatial average was taken over land only [to be consistent with the Willmott-Matsuura (WM) dataset] for all latitudes of the domain between the equator and the (Southern) tropic of Capricorn. Hence, the seasonal behavior of precipitation is clearly revealed. The southern Tropics experiences a dry season from May to September (austral winter) and a wet sea- 


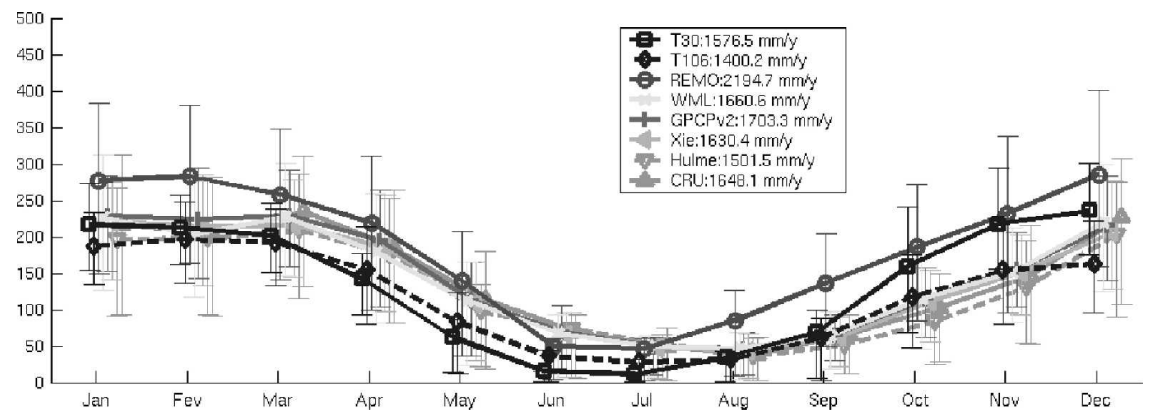

FIG. 1. Mean precipitation $\left(\mathrm{mm} \mathrm{month}^{-1}\right.$ ) over land for the datasets listed in Table 1. The datasets are averaged over the $1985-89$ period, at a latitude between $0^{\circ}$ and $23.5^{\circ} \mathrm{S}$ (i.e., between the equator and the tropic of Capricorn). Bars show the 25th and 75th percentiles over the averaged domain.

son from October to April (austral summer), about $80 \%$ of the annual precipitation. Since the spatial distribution of rainfall is far from Gaussian, we preferred to plot the 25th and 75th percentiles (first and third quartiles) in bars around the mean instead of the standard deviation in Fig. 1. All observational datasets display a similar behavior, reaching maximum values of 200-250 mm month ${ }^{-1}$ in January and March, and its minimum of $50 \mathrm{~mm}$ month $^{-1}$ in August. The tropical CRU dataset gives a $10 \%$ smaller estimate of December-February (DJF) precipitation $\left(1500 \mathrm{~mm} \mathrm{yr}^{-1}\right.$ ) as compared to an average $1650 \mathrm{~mm} \mathrm{yr}^{-1}$ for the WML, Global Precipitation Climatology Project (GPCP), Climate Prediction Center (CPC) Merged Analysis of Precipitation (CMAP), and CRU datasets. The interpolation methods produce fairly uniform datasets, since both the first and third quartiles do not differ from the mean by more than $50 \%$.

The T106 simulation by ECHAM is in reasonable agreement with the observational datasets, apart from underestimating precipitation in the late wet and dry season (April to July). It fails also to reproduce the double maxima in the wet season. As a consequence, the annual precipitation amounts to $1400 \mathrm{~mm} \mathrm{yr}^{-1}$, which underestimates by $15 \%$ the mean of the observations. Precipitation simulated by ECHAM T30 is closer to the observations (1570 $\left.\mathrm{mm} \mathrm{yr}^{-1}\right)$, but its seasonal cycle is early by 1-2 months, with a minimum in June-July. Common for both ECHAM simulations is a gross underestimation of dry season precipitation, with average values in July below $30 \mathrm{~mm} \mathrm{month}^{-1}$ for T106 and below $10 \mathrm{~mm} \mathrm{month}^{-1}$ for T30. REMO iso inherits the shifted seasonality of its host model, ECHAM T30, but reproduces the double maxima shape during the wet season (December and February). Precipitation amounts are overestimated all year-round, summing up to nearly $2200 \mathrm{~mm} \mathrm{yr}^{-1}$ (33\% more than the observations). $\mathrm{REMO}_{\text {iso }}$ third quartile values are significantly higher than both observation and $\mathrm{ECHAM}_{\text {iso }}$ values. Given that grid cells with steep mountain slopes display unrealistic monthly precipitation values $(>1000 \mathrm{~mm}$ month ${ }^{-1}$ ), part of the overestimation in mean precipitation can be explained by these outliers. Hence the median values for $\mathrm{REMO}_{\text {iso }}$ are only $21 \%$ higher than the observation average, whereas the mean values are $30 \%$ above the observation average.

The discrepancies in the annual cycle of mean precipitation are related to a mismatch in their spatial distribution. The maps of mean annual precipitation for the $\mathrm{REMO}_{\text {iso }}$ and ECHAM T106 and T30 simulations, compared to the WML, GPCP, and CMAP observa-

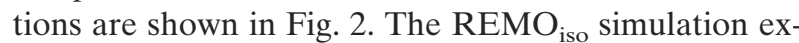
hibits extreme $\left(>1000 \mathrm{~mm}\right.$ month $\left.^{-1}\right)$ precipitation in several grid points with steep mountain slopes. At the same resolution, the WML dataset has a single point $\left(18^{\circ} \mathrm{S}, 65^{\circ} \mathrm{E}\right)$ where precipitation exceeds $800 \mathrm{~mm}$ month ${ }^{-1}$. On one hand, $\mathrm{REMO}_{\text {iso }}$ is likely to struggle dealing with moisture convergence increased by orographic uplift, which results in overestimated convective precipitation. The WML dataset records a punctual precipitation maximum of the same range but might fail in spite of the climatologically aided interpolation (CAI) algorithm to capture the physical orographic effect in remote, rain gauge scarce areas.

Precipitation patterns, shown in Fig. 2, differ between observations and simulations. All models overestimate precipitation amounts in the north-west Amazon basin, including the Guiana highlands, reaching $4000 \mathrm{~mm} \mathrm{yr}^{-1}$, but underestimate precipitation around the Amazon mouth, with less than $1500 \mathrm{~mm} \mathrm{yr}^{-1}$. Instead of precipitating over the coast, the simulated moisture is transported farther inland, to produce a second rain-out maximum at the topographic barrier of the Andes. This discrepancy is common to several modeling studies (Rojas and Seth 2003). The increased precipitation on the east flank of the cordillera is marked 

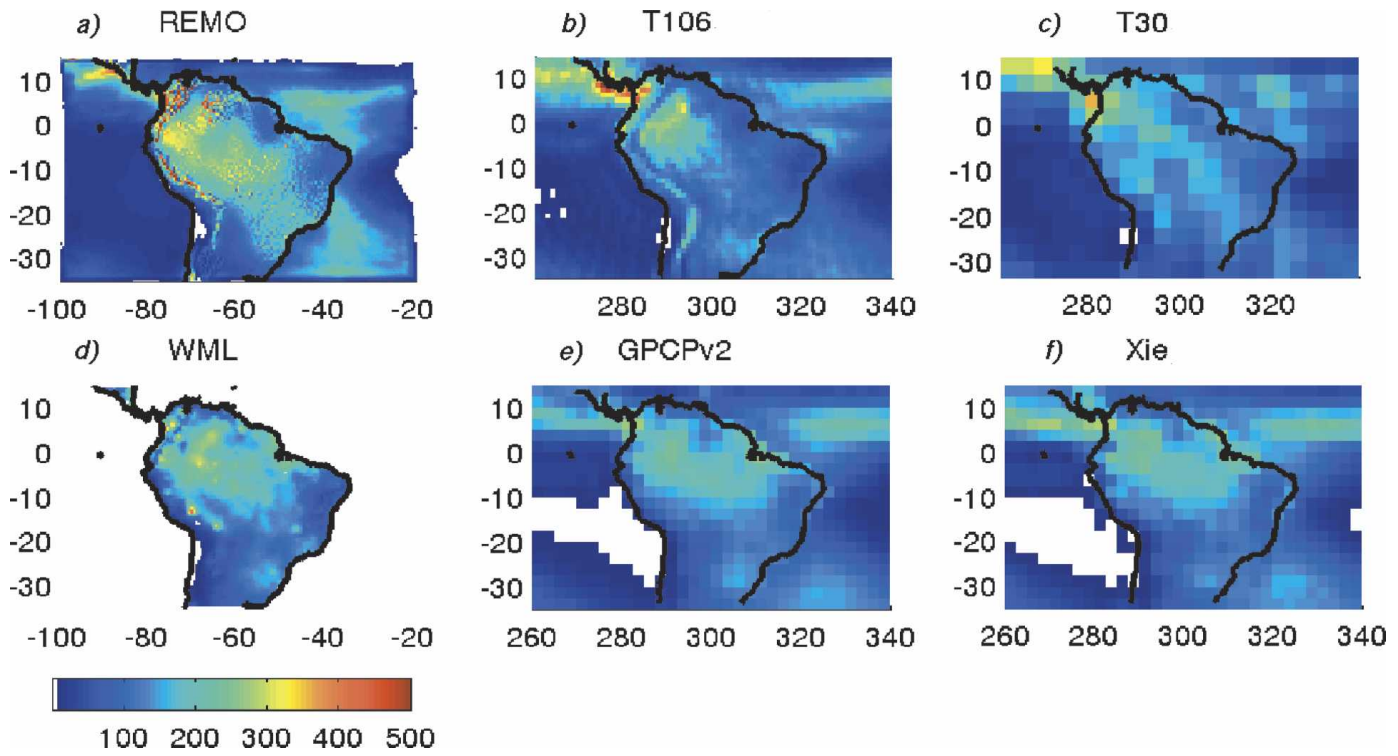

FIG. 2. Mean annual precipitation (mm month ${ }^{-1}$ ) simulated by (a) REMO, (b) ECHAM T106, and (c) ECHAM T30 as compared to gridded observations from (d) WML (Willmott and Matsuura 2001), (e) GPCP (Huffman and Bolvin 2004), and (f) CMAP (Xie and Arkin 2002).

in regional circulation models, as moisture converges due to low-level jets (LLJs: Vernekar et al. 2003). The different location of precipitation maxima is responsible for the apparent shifted seasonality in Fig. 1.

Similar discrepancies in simulated precipitation patterns are found in other studies. Costa and Foley (1998) indicate that reanalyses overestimate precipitation over the central and eastern Amazon basin. Both Goddard Space Flight Center (GSFC) and National Centers for Environmental Prediction (NCEP) datasets reach maxima in annual values of $3 \mathrm{~m} \mathrm{yr}^{-1}$ and above, as does $\mathrm{REMO}_{\text {iso. Lenters and Cook (1999) report precipita- }}$ tion maxima of $420 \mathrm{~mm}$ month $^{-1}$ during DJF, located at $10^{\circ} \mathrm{S}, 55^{\circ} \mathrm{W}$, in the global precipitation index (GPI) dataset, which even exceeds values by $\mathrm{REMO}_{\text {iso }}$. The presence of topography in a Geophysical Fluid Dynamics Laboratory (GFDL) GCM control simulation produces a local maximum of $450 \mathrm{~mm}$ month $^{-1}$ at $3^{\circ} \mathrm{N}$, $78^{\circ} \mathrm{W}$, which is shifted $5^{\circ}$ to the east with zonally uniform instead of observed SST, but vanishes in the nomountain experiment (Lenters and Cook 1995). The NCEP Eta model over South America, driven by NCEP reanalyses, locates correctly the mean precipitation over the Amazon delta but shows a similar excess as $\mathrm{REMO}_{\text {iso }}$ over the central Amazon basin; similarly to $\mathrm{REMO}_{\text {iso }}$, it produces excessive rainfall on the eastern slope of the Andes $\left(5^{\circ} \mathrm{S}, 75^{\circ} \mathrm{W}\right)$, due to increased moisture flux land inwards (Vernekar et al. 2003; Chou et al. 2000). Rojas and Seth (2003) nested the Regional Climate Model (RegCM) in the Community Climate
Model version 3 (CCM3) over South America. As in our case, both the GCM and the regional circulation models (RCM) overestimate precipitation in the western Amazon but underestimates it in the eastern part. Furthermore, the RCM also produces extreme rainfall $\left(>500 \mathrm{~mm}\right.$ month $^{-1}$ ) at $5^{\circ} \mathrm{S}, 75^{\circ} \mathrm{W}$, as over the Brazilian highland, in extreme wet conditions.

In conclusion, deficiencies noted in $\mathrm{REMO}_{\text {iso }}$ and ECHAM are widely shared in other circulation model studies over South America. REMO ${ }_{\text {iso }}$ generally overestimates precipitation throughout the year; however neither the seasonal variations nor the regional relative patterns are severely affected. The convective massflux parameterization scheme (Nordeng 1994; Aldrian et al. 2004) overestimates precipitation in the Tropics. Owing to intense evapotranspiration, atmospheric moisture is recycled over the Amazon basin. Hence, precipitation is maintained at high levels downstream. Nevertheless, $\mathrm{REMO}_{\text {iso }}$ reproduces increased orographic precipitation over the Andes, which is physically consistent. The latter is not captured by the gridded observation datasets. The most severe discrepancy (maxima at $5^{\circ} \mathrm{S}, 75^{\circ} \mathrm{W}$ instead of $5^{\circ} \mathrm{S}, 50^{\circ} \mathrm{W}$ in March) is inherited from the host simulation by ECHAM T30 and could possibly be improved with nudging procedures (von Storch et al. 2000; Seth and Rojas 2003). The difficulties for models to reproduce observed precipitation amounts over land and ocean are related to the complexity of cloud microphysics: few models are optimized for tropical convection. A fortiori, parameteriza- 

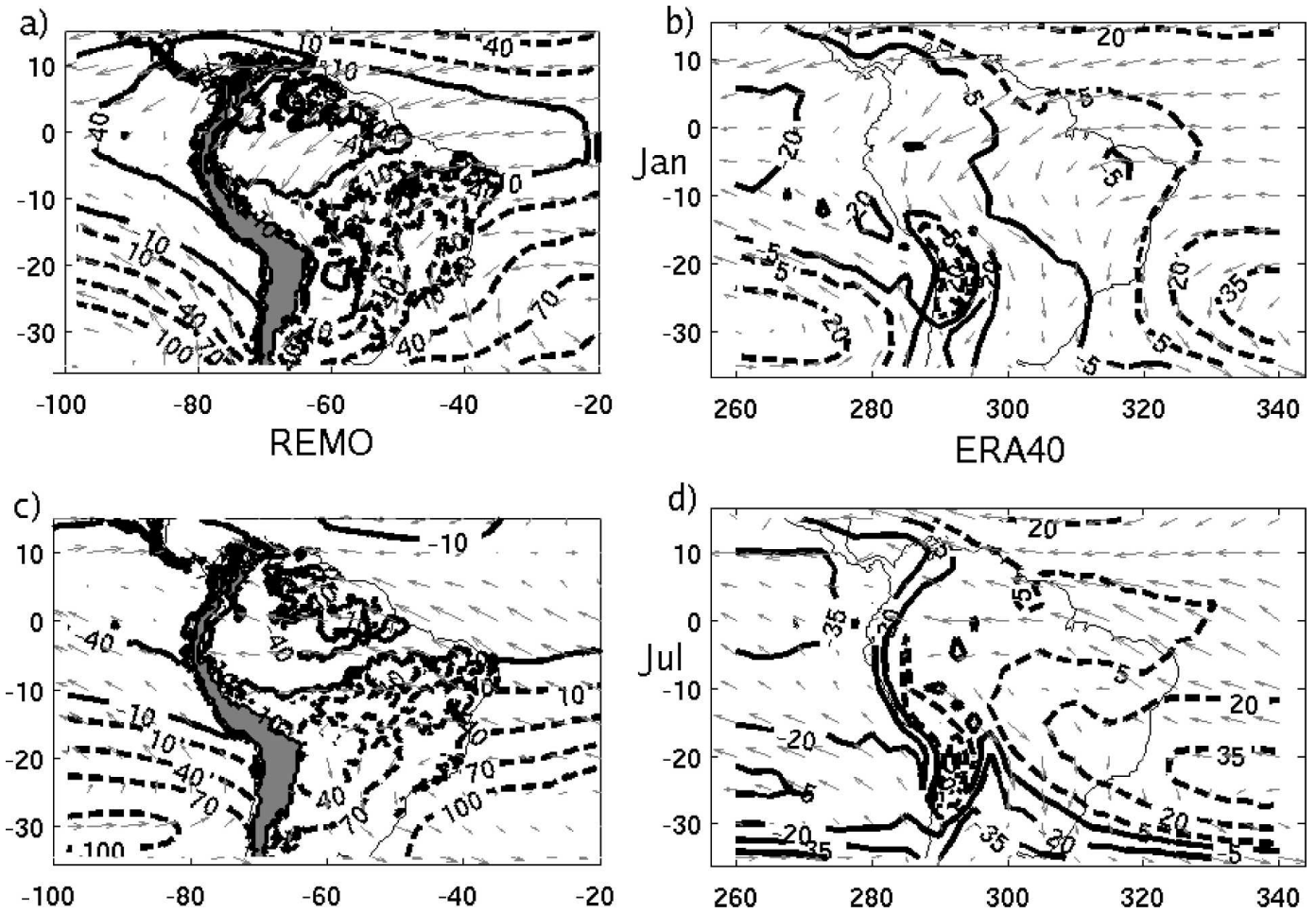

FIG. 3. Geopotential anomaly at $850 \mathrm{hPa}$ for (left) $\mathrm{REMO}_{\text {iso }}$ and (right) ERA, in (top) January and (bottom) July. Plain (dotted) lines represent positive (negative) anomalies. Arrows represent the mean wind field at $850 \mathrm{hPa}$. The Chaco low is marked by a depression at $20^{\circ} \mathrm{S}, 60^{\circ} \mathrm{W}$.

tions do not account successfully for the respective concentration of cloud condensation nuclei (i.e., aerosols) in the maritime and continental atmosphere.

\section{b. Atmospheric circulation}

The isotopic signature of a given rainfall is not only sensitive to local precipitation, but also to its integrated history along the parcel trajectory. Hence, a good knowledge of the regional circulation is essential for the interpretation of $\delta^{18} \mathrm{O}$ records. In the present section, we demonstrate how $\mathrm{REMO}_{\text {iso }}$ reproduces typical characteristics of atmospheric circulation over South America, before looking at the isotopic signal in the following section. Previous studies have shown the improved simulation of South American climate using a regional circulation model (Chou et al. 2000; Vernekar et al. 2003; Seth and Rojas 2003; Rojas and Seth 2003), as compared to global circulation models.

At first, we investigate geopotential height at $850 \mathrm{hPa}$ in $\mathrm{REMO}_{\text {iso }}$ and compare it with reanalyses data from ERA-40 (ECMWF 2003) in Fig. 3. Geopotential height at $850 \mathrm{hPa}$ was preferred to mean sea level pressure because the definition of the latter is equivocal. The problems cannot be avoided completely for geopoten- tial height, which is why we conduct a qualitative analysis of this field. ${ }^{1}$

Since the geopotential calculation method is different for $\mathrm{REMO}_{\text {iso }}$ and ERA-40, the resulting fields differ significantly both in absolute numbers and crossdomain variations. Nevertheless, some characteristic features of the South American meteorology are obvious for both datasets. $\mathrm{REMO}_{\text {iso }}$ reproduces the January subtropical Pacific high at $30^{\circ} \mathrm{S}, 90^{\circ} \mathrm{W}$, which moves equatorward by $5^{\circ}$ in July, in accordance with the ERA-40 reanalyses. On the other hand, the location of

\footnotetext{
${ }^{1}$ In $\mathrm{REMO}_{\text {iso }}$, geopotential height is computed as shown in Eq. (1):$$
\forall z>z_{s}, z(P)=z_{s}+\int_{P=850 \mathrm{hPa}}^{P s} \frac{R_{d} T_{\nu}(P) d P}{g P}
$$$$
z(P), z_{s} \text { : Geopotential height at } \mathrm{P}=850 \mathrm{hPa} \text {, surface }
$$$$
P, P s \text { : vertical pressure coordinate, surface pressure }
$$$$
R_{d}=287.04 \mathrm{~m}^{2} \mathrm{~s}^{-2} K^{-1}: \text { Gas constant for dry air }
$$$$
T_{\nu}(P)=T \frac{1+R_{\nu} / R_{d} e}{1+e} \approx T(1+\varepsilon e)[K]:
$$$$
\text { Virtual temperature at the pressure level } \mathrm{P}
$$$$
g=9.80665 \mathrm{~m} \mathrm{~s}^{-2} \text { : Gravity acceleration. }
$$ 


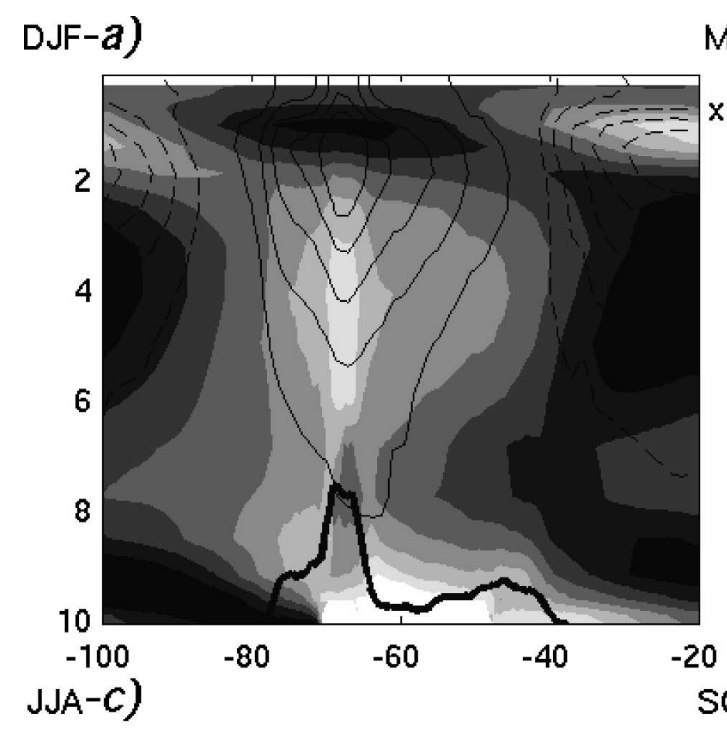

MAM-b)
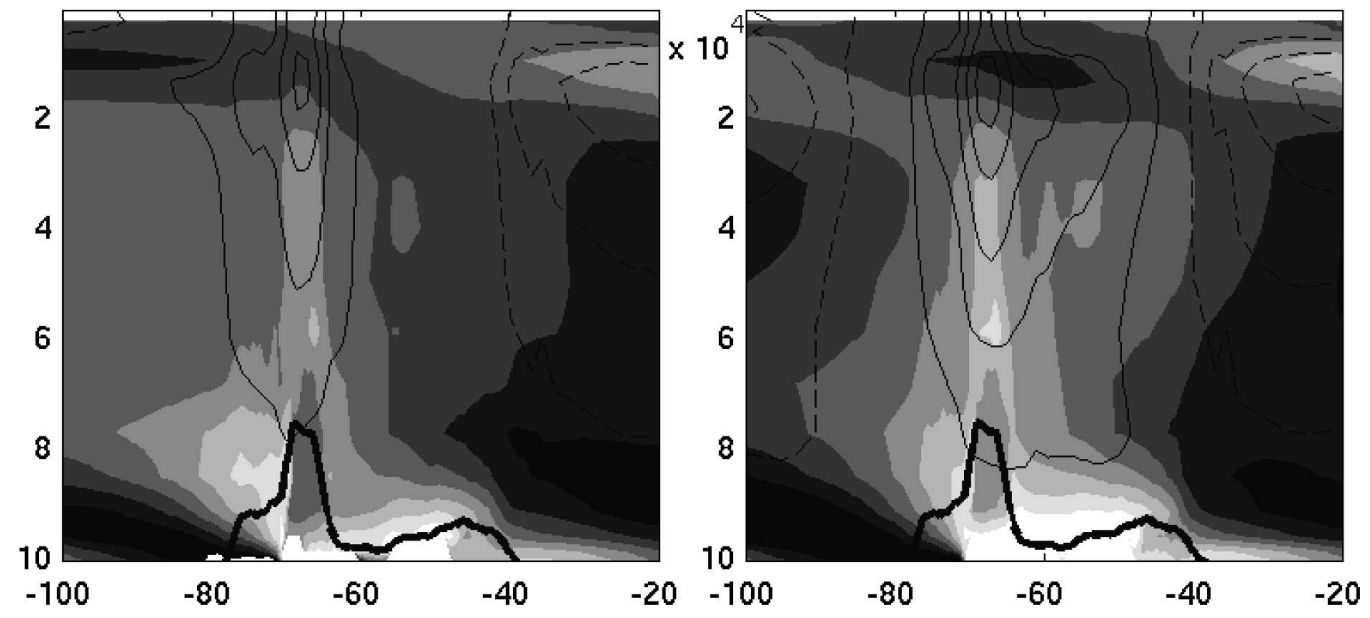

FIG. 4. Vertical cross section of virtual temperature anomaly (shaded, 1-K interval) and geopotential anomaly (contour interval: $10 \mathrm{~m}$, negative contours dashed) from zonal means averaged from $10^{\circ}$ to $25^{\circ} \mathrm{S}$, as simulated by $\mathrm{REMO}_{\text {iso }}$. The $x$ axis represents longitude (degrees), and the $y$ axis the pressure coordinate $(100 \mathrm{hPa})$.

the Atlantic in $\mathrm{REMO}_{\text {iso }}$ is $5^{\circ}$ too far south. Of special interest is a thermal low captured by $\mathrm{REMO}_{\text {iso }}$ in January at $20^{\circ} \mathrm{S}, 60^{\circ} \mathrm{W}$. It is referred to as the "Chaco Low" and determines, together with the Atlantic subtropical high, the location and intensity of the South Atlantic convergence zone (SACZ). This feature is not noticeable in ERA-40 because of its coarser resolution.

The Bolivian high $(\mathrm{BH})$ and its counterpart, the "Nordeste Low" ("NL"), are characterized by their geopotential heights. Figure 4 shows the vertical cross section at $\sim 12^{\circ} \mathrm{S}$ of geopotential and temperature deviations from their zonal mean. The Bolivian high builds up during SON, to reach its maximum in DJF. As described in Lenters and Cook (1997), the BH is then marked by a $50-\mathrm{m}$ increase in geopotential, centered at
$200 \mathrm{hPa} \sim 65^{\circ} \mathrm{W}$. This is the result of a warm core at $400 \mathrm{hPa}$, topped by a cold lens at $100 \mathrm{hPa}$. The Nordeste low, located at $\sim 20^{\circ} \mathrm{W}$, has an inverted structure: a cold core at $400 \mathrm{hPa}$ produces a decrease by $40 \mathrm{~m}$ in geopotential height at $200 \mathrm{hPa}$, topped by a warm core at 100 hPa. Similar to the GFDL GCM used by Lenters and Cook (1997), the warm core simulated by $\mathrm{REMO}_{\text {iso }}$ is lower than in the observations $(300 \mathrm{hPa})$. This points out an underestimation of deep convection with $\mathrm{REMO}_{\text {iso }}$ 's standard parameterization. In the absence of intense convection over the Amazon, the BH-NL vanishes during MAM and JJA. The remaining radiative heating over the Altiplano, and associated geopotential anomaly, leaves the $200-\mathrm{hPa}$ wind field unaltered. 

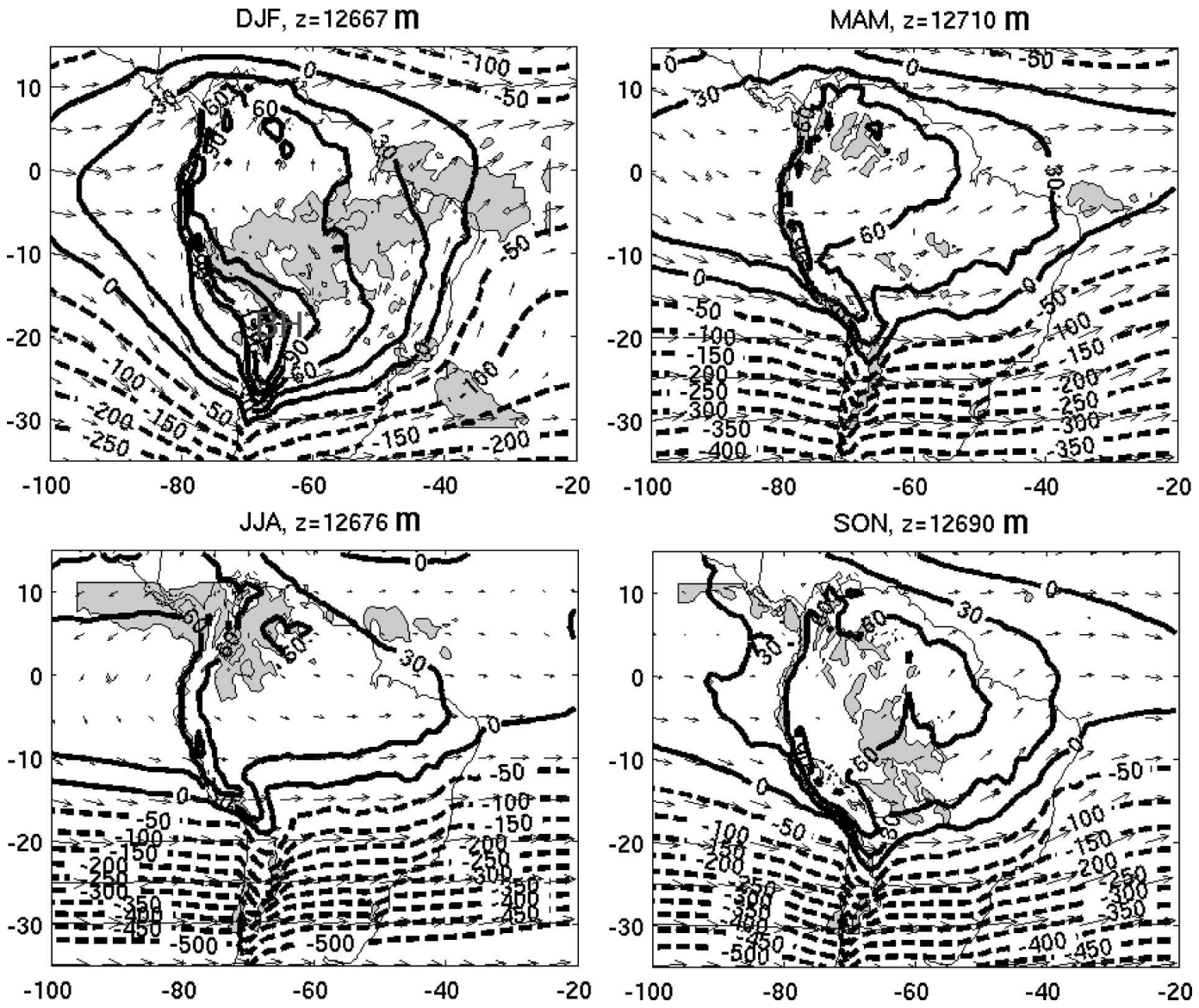

FIG. 5. Geopotential anomaly from the median $\bar{h}$ in meters at $200 \mathrm{hPa}$. Values for the median are $\bar{h}=12667 \mathrm{~m}$ in austral summer (DJF), $\bar{h}=12710 \mathrm{~m}$ in autumn (MAM), $\bar{h}=12676 \mathrm{~m}$ in winter (JJA), and $\bar{h}=12690 \mathrm{~m}$ in spring (SON). Positive (negative) contours are indicated with continuous (dashed) lines, in a $30-\mathrm{m}(50 \mathrm{~m})$ increment. Arrows represent the mean wind field at $200 \mathrm{hPa}$. Shaded areas indicate wind divergence at $200 \mathrm{hPa}$ exceeding the 75th percentile. The location of the Bolivian high is marked by "BH" during DJF.

The mean seasonal geopotential height, wind field, and divergence at $200 \mathrm{hPa}$ are shown in Fig. 5. It is possible to identify during DJF a synoptic maximum of geopotential, which lies $5^{\circ}$ north of the minimum of MSLP at $19^{\circ} \mathrm{S}, 63^{\circ} \mathrm{W}$ and marks the Bolivian high. The $\mathrm{BH}$ is further stressed by the anticyclonic (counterclockwise) vortex developing around it. On the opposite, the Nordeste low, located at $20^{\circ} \mathrm{S}, 22^{\circ} \mathrm{W}$, is characterized by a $100-\mathrm{m}$ decrease in geopotential height, which coincides with a cyclonic (clockwise) wind circulation. The major domain of divergence at $200 \mathrm{hPa}$ (corresponding to lower-troposphere convergence) is located to the north and east of the $\mathrm{BH}$. The areas of maximum 200-hPa convergence correspond to high precipitation (as compared to Figs. 2, 7, and 8). Strong convergence extends to the northeast over the Atlantic, joining the intertropical convergence zone. A second zone of convergence forms at $30^{\circ} \mathrm{S}, 30-40^{\circ} \mathrm{W}$, known as the South Atlantic convergence zone. In JJA, the geopotential height in the Southern Hemisphere adopts a zonal distribution, where both the $\mathrm{BH}$ and the NL vanish. The wind field, in geostrophic equilibrium, is perpendicular to the gradient of geopotential; that is, it flows as westerlies. The major zone of convergence (ITCZ) lies at $10^{\circ} \mathrm{S}$ over the Pacific and penetrates across the Andes into Columbia and Ecuador. This extensive convergence is responsible for the heavy precipitation over the eastern slope of the Andes. Intermediate seasons (MAM and SON) show the abrupt transition from the winter to the summer mode.

These results are in good agreement with Hastenrath (1997), reporting the location of the Bolivian high at $15^{\circ} \mathrm{S}, 65^{\circ} \mathrm{W}$ and similar divergence patterns. Lenters and Cook (1997) investigate the origin of the BH using

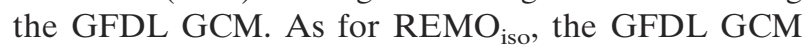
locates the $\mathrm{BH} 5^{\circ}$ to the southeast as compared to 

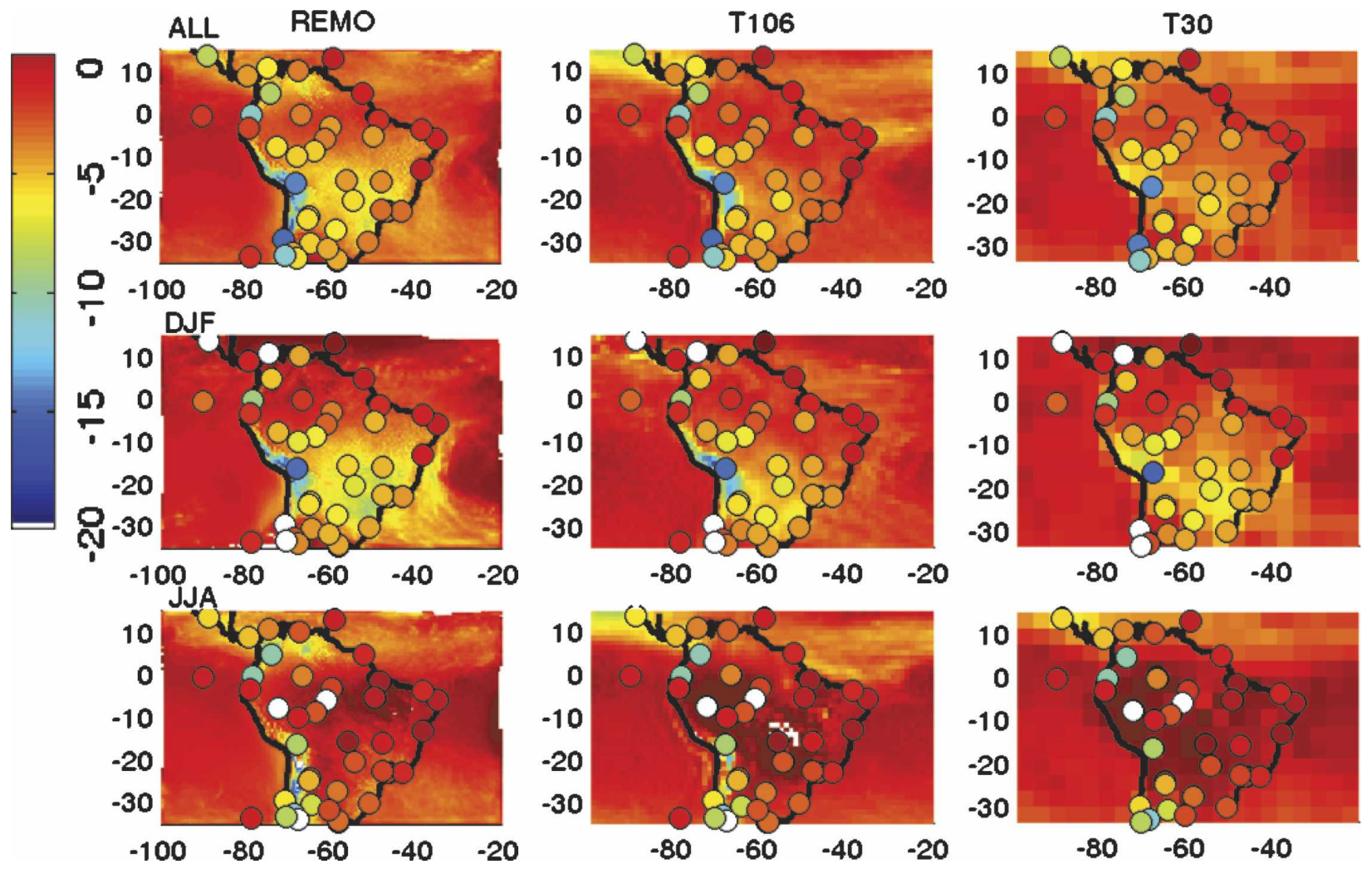

FIG. 6. Mean (top) annual, (middle) summer, and (bottom) winter precipitation $\delta^{18} \mathrm{O}(\%)$ for REMO, ECHAM T106, and ECHAM T30. Annual means from the GNIP climatology are represented as colored dots. Grid cells and GNIP station with precipitation amounts below $10 \mathrm{~mm}$ month $^{-1}$ are left blank.

NASA Data Assimilation Office (DAO) analyses. Latent heat release related to high convection over the Amazon is the primary cause of the BH. In second order, Lenters and Cook (1997) prove that the presence of the Andean relief (at T30 resolution) sharpens the $\mathrm{BH}$ and increases its geopotential anomaly by $30 \mathrm{~m}$. The higher resolution in $\mathrm{REMO}_{\text {iso }}$ confirms the latter with a geopotential anomaly exceeding $100 \mathrm{~m}$.

\section{c. Isotopic composition of precipitation}

The validity of ECHAM iso $_{\text {is }}$ has been demonstrated at various resolutions (Hoffmann 2003; Hoffmann et al. 2003; Vuille et al. 2003a). In the present section, we highlight the similarities and differences between REMO $_{\text {iso }}$ and ECHAM T106/T30 simulations. Evaluation is conducted primarily with the GNIP dataset, cited in Table 1.

The mean annual $\delta^{18} \mathrm{O}$ in precipitation for all models is shown in Fig. 6. All three simulations show similar spatial patterns over land, summarized as follows: 1) Comparably enriched precipitation over the central Amazon basin, roughly between $5^{\circ} \mathrm{N}$ and $10^{\circ} \mathrm{S}$ (e.g., $\overline{\delta^{18} \mathrm{O}}=-3.5 \%$ in Manaus: $3.12^{\circ} \mathrm{S}, 60.02^{\circ} \mathrm{W}$ ); 2) mod- erately depleted precipitation on the highlands of Guiana $\left(5^{\circ} \mathrm{N}, 65^{\circ} \mathrm{W}\right)$ and southern Brazil $\left(20^{\circ} \mathrm{S}, 50^{\circ} \mathrm{W}\right)$ [e.g., $\overline{\delta^{18} \mathrm{O}}=-5 \%$ in Campo Grande $\left(20.47^{\circ} \mathrm{S}, 54.67^{\circ} \mathrm{W}\right)$; 3) highly depleted precipitation on the Altiplano and the Andean Cordillera $\left(15^{\circ} \mathrm{S}, 70^{\circ} \mathrm{W}\right)$, with a magnitude increasing with the models resolution [e.g., $\overline{\delta^{18} \mathrm{O}}=$ $-14.5 /-12 /-7 \%$ or $\mathrm{REMO}_{\text {iso }} /$ ECHAM T106/ECHAM $\mathrm{T} 30$ in $\mathrm{La}$ Paz $\left.\left(16.29^{\circ} \mathrm{S}, 68.08^{\circ} \mathrm{W}\right)\right]$.

The $\mathrm{REMO}_{\text {iso }}$ simulation reproduces an oxygen isotope pattern resembling large-scale patterns similar to its host simulation, ECHAM T30. This means that no bias in mean annual $\delta^{18} \mathrm{O}$ is introduced by the regional model. On the other hand, contrasts between highlands and plains are enhanced in the $\mathrm{REMO}_{\text {iso }}$ simulation due to the improved resolution. The next section discusses the physical explanations of the altitude effect (discussion of Table 2). Besides the altitude effect, Fig. 6 reveals an reduced continental gradient over the Amazon basin. The relation between the latter and the neglected fractionation processes in the surface model is discussed in connection with Table 3 .

Spatial distribution of $\delta^{18} \mathrm{O}$ strongly varies according to the season. As shown in Fig. 7 for REMO iso $_{\text {[similar }}$ 
TABLE 2. Least squares linear regression of $\delta^{18} \mathrm{O}$ against altitude. The regression slope against altitude is given by $\Delta \delta^{18} \mathrm{O} / \Delta z$, with the squared correlation coefficient $r_{z}^{2}$ between $\delta^{18} \mathrm{O}$ and altitude. The asterisk replaces correlation coefficients that fail the $95 \%$ significance test.

\begin{tabular}{|c|c|c|c|}
\hline & \multirow[b]{2}{*}{ Model } & \multicolumn{2}{|l|}{ Altitude } \\
\hline & & $\Delta \delta^{18} \mathrm{O} / \Delta z(\% / 100 \mathrm{~m})$ & $r_{z}^{2}(\%)$ \\
\hline \multirow[t]{4}{*}{ Annual } & GNIP & -0.22 & 69 \\
\hline & REMO & -0.17 & 52 \\
\hline & T106 & -0.16 & 68 \\
\hline & $\mathrm{T} 30$ & -0.051 & 7.1 \\
\hline \multirow[t]{4}{*}{ DJF } & GNIP & -0.23 & 60 \\
\hline & REMO & -0.17 & 24 \\
\hline & T106 & -0.16 & 50 \\
\hline & $\mathrm{T} 30$ & -0.11 & 8.7 \\
\hline \multirow[t]{4}{*}{ MAM } & GNIP & -0.25 & 67 \\
\hline & REMO & -0.17 & 55 \\
\hline & T106 & -0.15 & 66 \\
\hline & Т30 & -0.035 & 7.8 \\
\hline \multirow[t]{4}{*}{ JJA } & GNIP & -0.19 & 45 \\
\hline & REMO & -0.16 & 39 \\
\hline & T106 & -0.095 & 21 \\
\hline & T30 & 0.076 & $*$ \\
\hline \multirow[t]{4}{*}{ SON } & GNIP & -0.19 & 55 \\
\hline & REMO & -0.14 & 41 \\
\hline & T106 & -0.11 & 40 \\
\hline & $\mathrm{T} 30$ & 0.03 & 9.3 \\
\hline
\end{tabular}

maps for ECHAM T106 and T30 can be found in Hoffmann et al. (2003) and Vuille et al. (2003a)], high precipitation is characterized by low $\delta^{18} \mathrm{O}$, underlining the amount effect (AE; Dansgaard 1964). Furthermore, the rainy season records a northwest-southeast gradient of $\delta^{18} \mathrm{O}$, decreasing from the central Andes to the Paraná region. The horizontal moisture transport $\mathbf{H}$ in Fig. 7 shows that Amazonian moisture is transported by strong winds from the central Andes to the Paraná region. Rao et al. (1996) reports similar figures for vertically integrated moisture transport throughout the year. This low-level motion is associated with high convergence in summer (shown in Fig. 5) and increasing precipitation along the path. Meridional flow combines with progressive rain-out to produce the progressive depletion of precipitation between the origin of LLJs $\left(10^{\circ} \mathrm{S}, 70^{\circ} \mathrm{W}\right)$ and the maximum precipitation associated with the continental extension of the SACZ at $20^{\circ} \mathrm{S}, 45^{\circ} \mathrm{W}$. Advection of moist air along the Andean ridge by LLJs, causing excessive precipitation in the continental SACZ extension, is referred to as the "South American Monsoon System" ("SAMS"). The northwest-southeast $\delta^{18} \mathrm{O}$ gradient proves that stable water isotopes are a good proxy of the SAMS. This aspect is investigated in a separate study (Sturm et al. 2007).

JJA $\delta^{18} \mathrm{O}$, shown in Fig. 8, is typical for the dry season isotopic signature. The weak continental gradient observed in annual means (Fig. 6) vanishes, with maximum $\delta^{18} \mathrm{O}$ around $7^{\circ} \mathrm{S}, 45^{\circ} \mathrm{W}$. This is in contradiction with the classical inland depletion of $\delta^{18} \mathrm{O}$-enriched, maritime air masses. High $\delta^{18} \mathrm{O}$ values (between $0 \%$ and $-2 \%$ ) propagate from the Amazon basin along the east flank of the Andes, reaching subtropical latitudes $\left(30^{\circ} \mathrm{S}\right)$. Thus $\delta^{18} \mathrm{O}$ marks the persistence of low-level jets during JJA, albeit with lesser strength than summer (Vera 2002). A comparison of the $\delta^{18} \mathrm{O}$ gradient across the Amazon basin between REMO ${ }_{\text {iso }}$, ECHAM T106, ECHAM T30, and GNIP is presented in the next section.

To assess the model skill in representing both the mean value and seasonal variations of the isotopic signal, we computed the figure of merit in time $\left(\mathrm{FMT}^{2}\right)$ respective to GNTP monthly values. The skills are very similar for all three models: FMTs generally lie between 0.6 and 0.8 in the subtropics but reach their minimum values (0.4) in the Amazon. Resolution marginally improves the skills: the median FMT for ECHAM T30, ECHAM T106, and $\mathrm{REMO}_{\text {iso }}$ is, respectively, $0.515,0.567$, and 0.585 .

One limitation of the FMT is that mean gridcell precipitation at different resolutions is compared to station measurements. A more consistent way of comparing model results with each other is to upscale at the coarsest resolution prior to comparing the results. We averaged the results over a $5^{\circ} \times 5^{\circ}$ box: for ECHAM T30, this box covers 2-4, for ECHAM T106 16-25, and for $\mathrm{REMO}_{\text {iso }} 101$ grid cells. We compare the average value and the 25th and 75th percentiles of model data to the point measurements of stations contained in the box. We select three locations of particular climatic interest for this study: a coastal area around Cayenne $\left(0^{\circ}-5^{\circ} \mathrm{N}, 52^{\circ}-57^{\circ} \mathrm{W}\right)$, an Amazonian area around

\footnotetext{
${ }^{2}$ Figure of merit in time is defined as follows:

$$
\mathrm{FMT}=\frac{\sum_{i=1}^{12} \min \left(\left|\delta^{18} \mathrm{O}_{\mathrm{mod}}(i)\right|,\left|\delta^{18} \mathrm{O}_{\mathrm{GNIP}}(i)\right|\right)}{\sum_{i=1}^{12} \max \left(\left|\delta^{18} \mathrm{O}_{\mathrm{mod}}(i)\right|,\left|\delta^{18} \mathrm{O}_{\mathrm{GNIP}}(i)\right|\right)},
$$
}

where $\delta^{18} \mathrm{O}(i)$ represents the monthly value, "mod" stands for simulations, and "GNIP" for observations. In case of perfect agreement, FMT equals 1, and decreases toward 0 otherwise. 
TABLE 3. $\delta^{18} \mathrm{O}$ and precipitation continental gradient along the Amazon basin. Results are weighted latitudinally between $0^{\circ}$ and $10^{\circ} \mathrm{S}$. In the case of GNIP, nine stations within the averaging domain are taken into account. Linear regression with longitude is computed on a $75^{\circ}$ and $35^{\circ} \mathrm{W}$ transect. Sign convention is such that a $\Delta / \Delta \lambda>0$ if it is increasing with continentality. Since easterlies dominate over the Amazon, the continental gradient $\Delta / \Delta \lambda$ is of opposite sign to the longitudinal gradient $\Delta / \Delta L$. For $\delta^{18} \mathrm{O}$ (precipitation), the slope is given in $\% / 10^{\circ}\left(\mathrm{mm} / 10^{\circ}\right)$. Asterisks indicate regressions that fail the $95 \%$ significance test.

\begin{tabular}{|c|c|c|c|c|c|c|c|}
\hline & \multirow[b]{2}{*}{ Model } & \multicolumn{3}{|c|}{$\delta^{18} \mathrm{O}$} & \multicolumn{3}{|c|}{ Precipitation } \\
\hline & & $\delta^{18} \mathrm{O} \%$ & $\Delta \delta^{18} \mathrm{O} / \Delta \lambda\left(\% / 10^{\circ}\right)$ & $r_{\delta}^{2}$ & $\bar{P} m m$ & $\Delta P / \Delta \lambda m m / 10^{\circ}$ & $r_{P}^{2}$ \\
\hline \multirow[t]{4}{*}{ Annual } & GNIP & -4.50 & -1.1 & $82 \%$ & 180 & $*$ & $*$ \\
\hline & REMO & -4.09 & 0.13 & $51 \%$ & 194 & 46 & $93 \%$ \\
\hline & T106 & -3.15 & 0.26 & $37 \%$ & 130 & 39 & $82 \%$ \\
\hline & T30 & -3.94 & $*$ & $*$ & 135 & 17 & $71 \%$ \\
\hline \multirow[t]{4}{*}{ DJF } & GNIP & -4.05 & -1.2 & $58 \%$ & 212 & $*$ & $*$ \\
\hline & REMO & -3.88 & 0.32 & $50 \%$ & 271 & 19 & $44 \%$ \\
\hline & $\mathrm{T} 106$ & -3.16 & $*$ & $*$ & 171 & 29 & $78 \%$ \\
\hline & Т30 & -3.97 & * & $*$ & 215 & $*$ & $*$ \\
\hline \multirow[t]{4}{*}{ MAM } & GNIP & -6.15 & -1.5 & $93 \%$ & 257 & $*$ & * \\
\hline & REMO & -4.80 & $*$ & $*$ & 262 & 31 & $77 \%$ \\
\hline & T106 & -3.93 & * & $*$ & 193 & 32 & $58 \%$ \\
\hline & $\mathrm{T} 30$ & -3.64 & * & $*$ & 160 & 5.7 & $20 \% *$ \\
\hline \multirow[t]{4}{*}{ JJA } & GNIP & -2.72 & -0.39 & $20 \% *$ & 125 & $*$ & $*$ \\
\hline & REMO & -1.33 & $*$ & $*$ & 69 & 42 & $84 \%$ \\
\hline & T106 & -1.42 & 1.3 & $85 \%$ & 56 & 26 & $54 \%$ \\
\hline & T30 & -0.62 & 0.36 & $46 \%$ & 22 & 13 & $49 \%$ \\
\hline \multirow[t]{4}{*}{ SON } & GNIP & -2.04 & -0.48 & $22 \% *$ & 107 & $*$ & $*$ \\
\hline & REMO & -3.49 & -0.94 & $94 \%$ & 172 & 92 & $85 \%$ \\
\hline & T106 & -2.32 & -0.24 & $35 \%$ & 102 & 71 & $91 \%$ \\
\hline & T30 & -4.71 & $*$ & $*$ & 142 & 57 & $75 \%$ \\
\hline
\end{tabular}

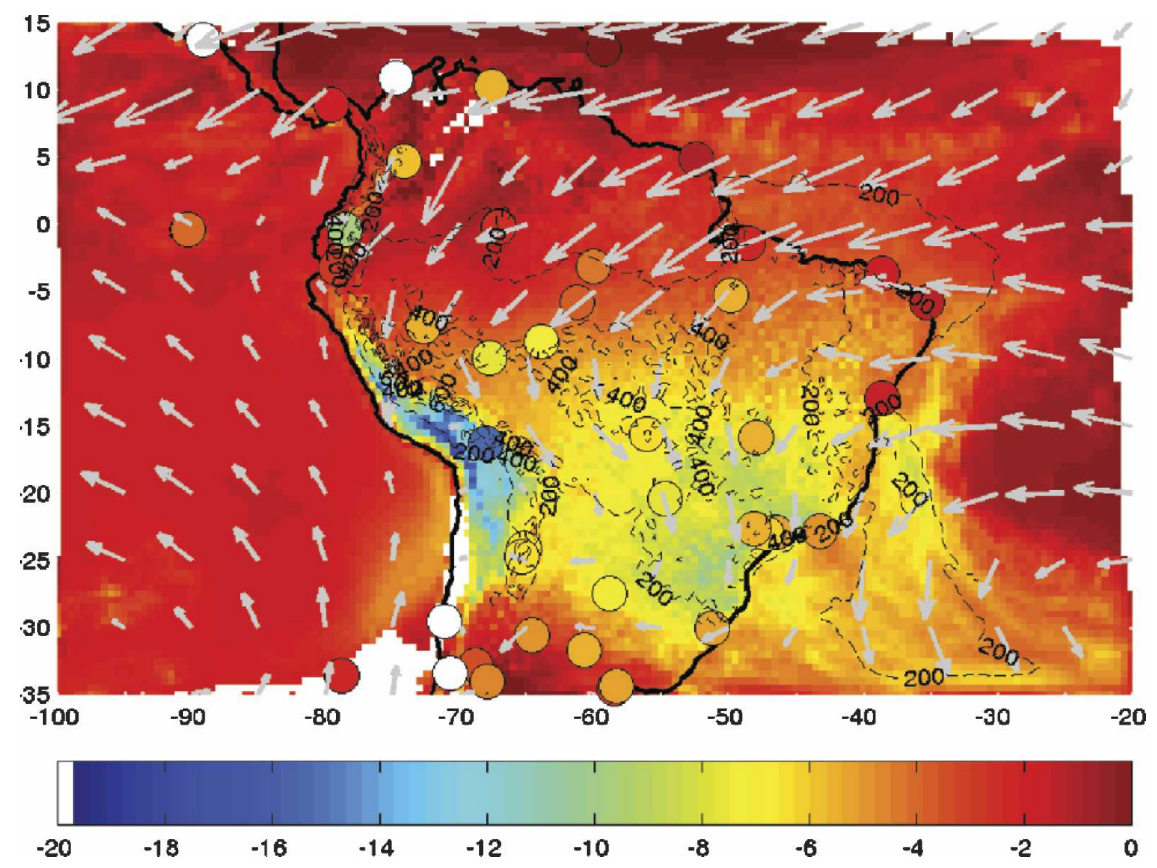

FIG. 7. Mean austral summer $\delta^{18} \mathrm{O}$ in precipitation (\%) for REMO. Contours represent the precipitation amounts $\left(\mathrm{mm}\right.$ month $\left.^{-1}\right)$, and arrows the horizontal vapor transport. GNIP mean values over the same period are represented as colored dots. Grid cells and GNIP station with precipitation amounts below $10 \mathrm{~mm}$ month $^{-1}$ are left blank. 


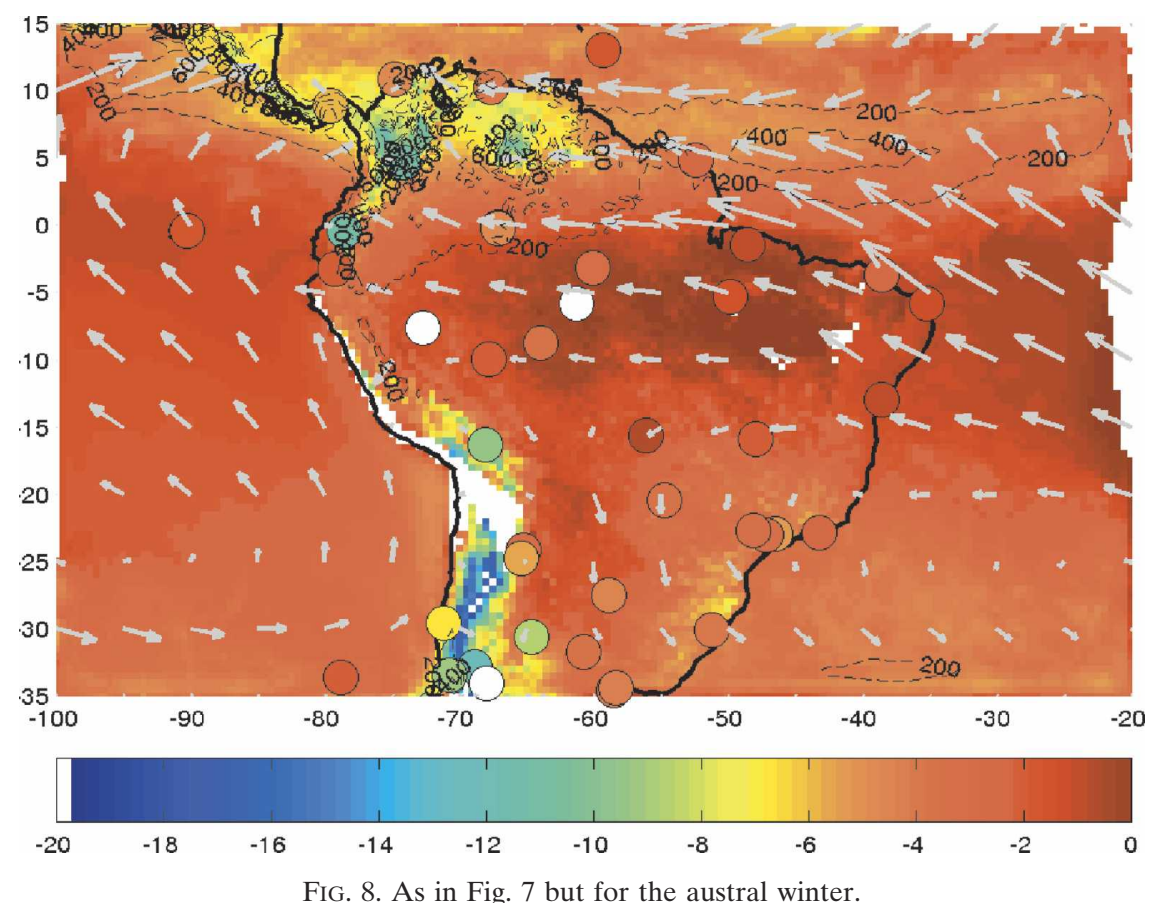

Manaus $\left(2^{\circ}-7^{\circ} \mathrm{S}, 58^{\circ}-63^{\circ} \mathrm{W}\right)$, and an area at the foothills of the Andes around Porto Velho $\left(7^{\circ}-12^{\circ} \mathrm{S}, 62^{\circ}-\right.$ $\left.67^{\circ} \mathrm{W}\right) .^{3}$

The climatologies of $\delta^{18} \mathrm{O}$ and precipitation for each box are shown in Fig. 9. The precipitation climatologies reflect the same deficiencies as reported in the previous section (cf. Figs. 1 and 2). The GNIP precipitation in Cayenne nevertheless overestimates the precipitation by $33 \%$ as compared to the WML dataset. The shape of the precipitation curves shift from the inner Tropics (Cayenne and Manaus), with a double peak in the wet season (twice yearly passage of the ITCZ), to the outer Tropics (Pôrto Velho), with a single peaked wet season (once yearly passage of the ITCZ). In the coastal area, all four datasets have in common a weak seasonal amplitude (difference between maximal and minimal monthly value) of the $\delta^{18} \mathrm{O}$ signal, although it is well pronounced for precipitation. No significant deviation in $\delta^{18} \mathrm{O}$ is observed between the three models. Simulated $\delta^{18} \mathrm{O}$ is underestimated by $3 \%$ from October to January, corresponding to the first peak of the wet season. Furthermore, precipitation is more depleted during the first peak, although the local precipitation amounts are larger during the second peak. This con-

\footnotetext{
${ }^{3}$ Pôrto Velho, in Brazil, is not strictly speaking at the foothills of the Andes. Yet the climatologies are very similar to the southward-shifted box $\left(2-7^{\circ} \mathrm{S}, 62-67^{\circ} \mathrm{W}\right.$; Zongo valley in the Yungas). Unfortunately, no GNIP is available in the Zongo box, thus we preferred to show results around Pôrto Velho.
}

tradicts a "linear" interpretation of the amount effect. In the Amazon region, the seasonal amplitude reaches $6 \%$ for all datasets, increasing as a result of continentality. Even if a correction is estimated for the excess precipitation from September to December, all models overestimate $\delta^{18} \mathrm{O}$ by $3 \%$ all year round. ECHAM T30 produces more rain during the first peak than during the second one; accordingly, the precipitation is more depleted during the first peak than during the second. The inverse occurs for the ECHAM T106 run, yet precipitation during the second peak is less depleted than expected from a linear amount effect. $\mathrm{REMO}_{\text {iso }}$ overestimates precipitation as compared to ECHAM T30, but without being more depleted. The minimum $\delta^{18} \mathrm{O}$ occurs in May, that is, one month after the maximum in precipitation. In the Andean foothills, $\mathrm{REMO}_{\text {iso }}$ 's precipitation agrees best with the GNIP and WML datasets. Remarkably, the $\delta^{18} \mathrm{O}$ signal conserves a double peaked shape even though precipitation does not exhibit this feature. Models overestimate $\delta^{18} \mathrm{O}$ by $5 \%$ during the dry season (July to September) and the late wet season (February to April).

Several conclusions can be drawn from these observations. First, the permanent positive bias in $\delta^{18} \mathrm{O}$ at Manaus is caused by the nonfractionating transpiration fluxes at the surface, which is imprinted in the precipitation $\delta^{18} \mathrm{O}$ during its partial subcloud reevaporation. Currently, all vapor flux at the surface is considered nonfractionating. This simplistic parameterization is dictated by the monolayer (bucket-type) soil module 

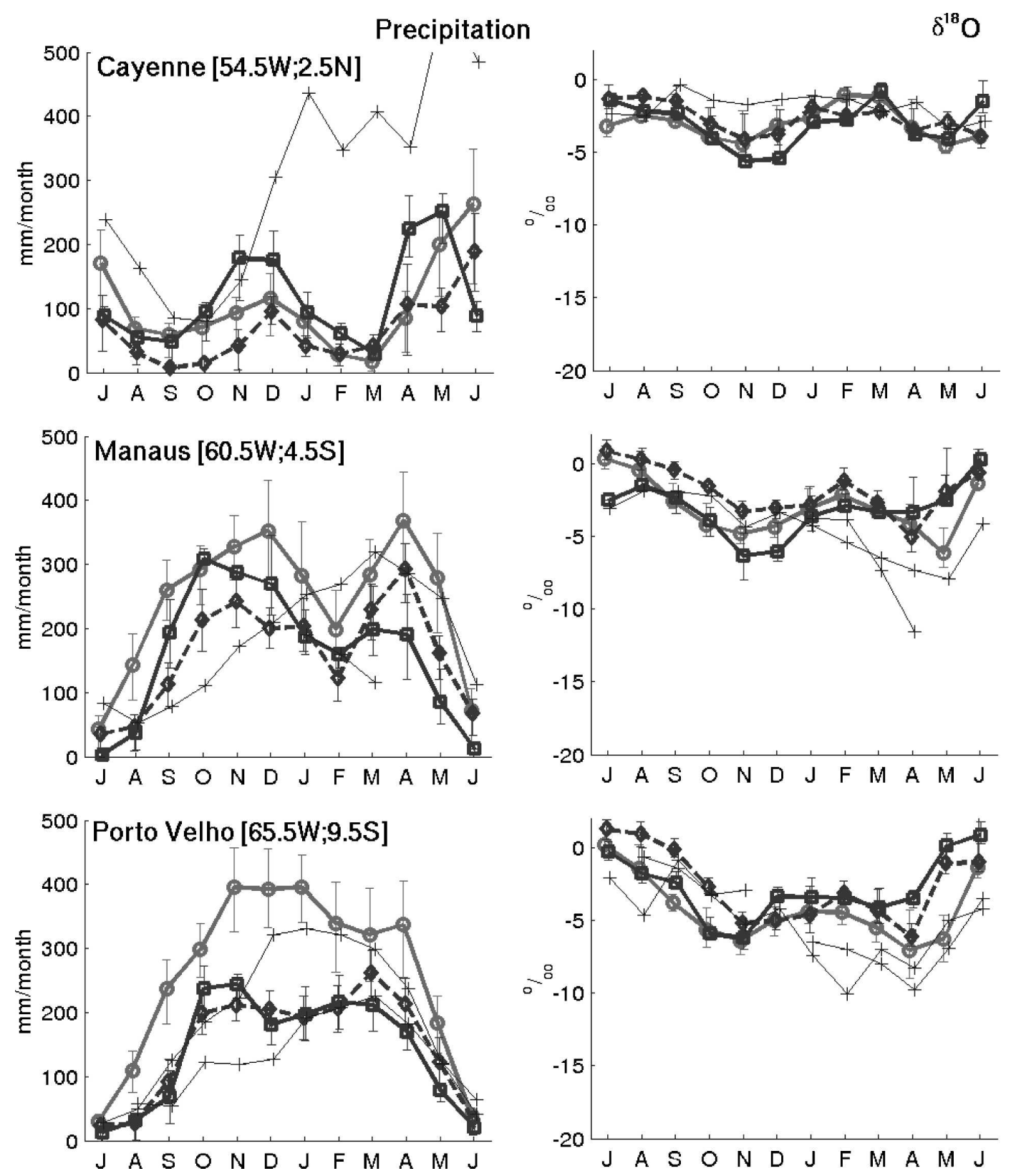

FIG. 9. (left) Precipitation ( $\mathrm{mm}$ month $^{-1}$ ) and (right) $\delta^{18} \mathrm{O}(\%)$ climatologies for REMO (light gray circles), T106 (dotted black diamonds), and T30 (black squares). Precipitation and $\delta^{18} \mathrm{O}$ are averaged over a $5^{\circ} \times 5^{\circ}$ box centered, respectively, at $2.5^{\circ} \mathrm{N}, 54.5^{\circ} \mathrm{W}, 4.5^{\circ} \mathrm{S}, 60.5^{\circ} \mathrm{W}, 9.5^{\circ} \mathrm{S}, 65.5^{\circ} \mathrm{W}$. The error bars show the first and third quartile (i.e., 25 th and 75 th percentiles) for grid cells within the box, covering 5 years of data. GNIP stations within the box (respectively, Cayenne, Manaus, and Pôrto Velho) are depicted with thin crosses.

and overestimates $\delta^{18} \mathrm{O}$ in two ways. Field experiments (e.g., Lai et al. 2006) demonstrate that, under the assumption that steady state is reached for transpiration by plants, the water vapor released by the leaves will have the same isotopic signature as the water taken up by the roots. Yet root zone moisture is usually more depleted than the bulk soil moisture since it is preferably recharged by intense, depleted rainfall events.
Evaporation from bare ground and open water surfaces is fractionating, so the vapor is depleted relative to its source water. Since such subgrid characteristics are not taken into account in $\mathrm{REMO}_{\text {iso }}$ 's physical scheme, it is not possible at this stage to implement any isotopic fractionation processes. This study demonstrates that evaporation from open water bodies (rivers, ponds, puddles), and the inherent kinetic and thermodynamic 
fractionation cannot be neglected, especially during the dry season. During the dry season, water recycling (evaporation and convective precipitation) over the Amazon exceeds the mesoscale advection of moisture. This underestimation of the continental gradient during the dry season is shared by the by the ECHAM T106 model, as well as the isotope-enabled GISS II GCM (Vuille et al. 2003a). Second, analysis of the backtrajectories from Cayenne for water vapor explains the different isotopic signature of the double wet season. In MAM, the ITCZ lies to the south of Cayenne, and air masses are "drifted" by northern westerlies. Hence moisture precipitating over Cayenne originates from the nearby tropical Atlantic with a less depleted initial state. In SON, the ITCZ has traveled north of Cayenne, and the southern westerlies prevail. Hence moisture originates from the colder, subtropical South Atlantic, with a more depleted initial isotopic composition. Third, the $\delta^{18} \mathrm{O}$ signal clearly appears as an integrated proxy of precipitation: the isotopic signal at Pôrto Velho depends not only on the local precipitation rate, but rather on the cumulated precipitation from Cayenne, over Manaus, to Pôrto Velho. The next section investigates further this point, by quantifying the amount effect along an air parcel trajectory.

\section{Climatic interpretation of the water isotope signal}

\section{a. The simulated altitude effect}

Altitude appears as the mean control on the mean annual $\delta^{18} \mathrm{O}$ distribution (Fig. 6). To quantify the major relationship between $\delta^{18} \mathrm{O}$ and altitude, a linear regression of $\delta^{18} \mathrm{O}$ against altitude was performed. Furthermore, The $\delta^{18} \mathrm{O}$ distribution is proven to display large seasonal variations. Hence the regression was computed both for annual and seasonal means. The regression slopes, along with the squared correlation coefficients, are listed in Table 2. The regression on geographical coordinates does not succeed in capturing the $\delta^{18} \mathrm{O}$ variability simulated by ECHAM T30. Hence this coarse-resolution simulation is not discussed further in the present paragraph. Furthermore, the spatial inhomogeneity of GNIP station locations makes the interpretation of its regression parameters questionable. In the following, we concentrate on the $\mathrm{REMO}_{\text {iso }}$ and ECHAM T106 simulations.

For both datasets, more than half of the $\delta^{18} \mathrm{O}$ variance is related to altitude. The annual regression slope $\Delta \delta^{18} \mathrm{O} / \Delta z \sim-0.2 \% / 100 \mathrm{~m}$ is similar for models and GNIP observations. Simulated altitude gradients are in fair agreement with observational evidence. Gonfiantini et al. (2001) and Roche et al. (1999) report altitude gradients along the Yungas Valley (Bolivia) between
-0.148 and $-0.239 \% / 100 \mathrm{~m}$, which is slightly steeper than gradients observed on Mount Cameroun. Tropical $\delta^{18} \mathrm{O}$ altitude gradients are among the weaker values worldwide, which range from -0.4 to $-0.16(\% / 100 \mathrm{~m})$ (Siegenthaler and Oeschger 1980). Vogel et al. (1975) report altitude gradients in the midlatitude Argentina between -0.6 and $-0.1 \%(/ 100 \mathrm{~m})$.

Although the relative control $\left(r^{2}\right)$ of the altitude effect varies throughout the seasons, the regression slopes remain remarkably stable $( \pm 0.01 \% / 100 \mathrm{~m})$. This characterizes the "altitude effect": a moist air mass rising along a mountain slope gradually rains out (orographic precipitation), while temperature steadily decreases. These two features explain why $\delta^{18} \mathrm{O}$ decreases with altitude. In accordance with Gonfiantini et al. (2001), the altitude gradient is slightly larger during the rainy season (DJFMAM) than the dry season (JJASON), because of enhanced orographic rainout. During DJF, the altitude control reaches its minimum for $\mathrm{REMO}_{\text {iso }}\left(r^{2}=24 \%\right)$, and second smallest value for ECHAM T106 $\left(r^{2}=49 \%\right)$. The altitude control is weak too during JJA (REMO ${ }_{\text {iso }}: r^{2}=39 \%$; ECHAM T106: $\left.r^{2}=21 \%\right)$.

With the increased resolution by $\mathrm{REMO}_{\text {iso }}$, it is possible to look not only at the first, but also at the second derivative of $\delta^{18} \mathrm{O}$ with altitude. Because climatic contexts all across the north-south transect of the Andes are merged, the quantitative approach is limited. Nevertheless, such an analysis reveals that $\partial^{2} \delta^{18} \mathrm{O} / \partial z^{2}>0$. Because of a lack of high-altitude grid points, no such tendency appears in the ECHAM T106 dataset. This behavior is confirmed by observations: Roche et al. (1999) reports an increased (absolute) altitude gradient $\partial \delta^{18} \mathrm{O} / \partial z$ in the Bolivian Andes. Based on comprehensive measurements, Vimeux et al. (2005) demonstrates that air masses lifted uphill along the Zongo Valley (Bolivia) undergo a pseudo-Rayleigh distillation, with approximately $15 \%$ of the condensed water remaining in the cloud. The quadratic fit of $\partial \delta^{18} \mathrm{O} / \partial z$ by $\mathrm{REMO}_{\text {iso }}$ resembles a pure Rayleigh distillation, assuming a tropospheric lapse rate of $-6.5^{\circ} \mathrm{km}^{-1}$ and an initial relative humidity of $80 \%$, as modeled by Gonfiantini et al. (2001). Hence $\mathrm{REMO}_{\text {iso }}$ seems to capture the trend of Rayleigh distillation along the valleys correctly, but its moisture advection scheme is not able to reproduce the upward lifting of clouds.

\section{b. Continental gradient across the Amazon basin}

The issue of continental effect over South America was briefly addressed in connection with Table 2 . In the present paragraph, we focus on the longitudinal gradient of $\delta^{18} \mathrm{O}$ and precipitation across the Amazon basin.

The longitudinal transect is taken over $75^{\circ}-35^{\circ} \mathrm{W}$ 
(which eliminates the effect of the Andes) averaged latitudinally between $0^{\circ}$ and $10^{\circ} \mathrm{S}$. For GNIP, nine stations within the area of interest are used in the computation. Linear regression of $\delta^{18} \mathrm{O}$ and precipitation against continentality $\lambda$ (longitude with opposite sign, such as regression slopes $\Delta / \Delta \lambda$, are of opposite sign to $\Delta / \Delta L$, hence $\delta^{18} \mathrm{O}$ decreasing inland have negative $\Delta \delta^{18} \mathrm{O} / \Delta \lambda$ values) are shown in Table 3 .

The continental $\delta^{18} \mathrm{O}$ gradient for mean annual GNIP values is negative, consistent with the inland depletion of precipitation. The slope for the nine GNIP stations $\left(-1.1 \% / 10^{\circ}\right)$ is steeper than reported by Salati et al. (1979) $\left(-0.68 \% / 10^{\circ}\right)$, based on 16 stations across the Amazon basin. The annual $\delta^{18} \mathrm{O}$ gradient for $\mathrm{REMO}_{\text {iso }}$ and ECHAM T106 are weakly positive, which contradicts the classical continental effect. This discrepancy is further observed on a seasonal basis. $\mathrm{REMO}_{\text {iso }}$ displays a strong positive continental gradient during DJF. Figure 6 proves that this artifact is due to a hidden latitudinal gradient: $\delta^{18} \mathrm{O}$ is most depleted in the southwestern part of the transect (high precipitation over the Brazilian highlands in connection with the ITCZSACZ), whereas it is most enriched in the northeastern part (dry conditions in the northern Amazon). Salati et al. (1979) reports continental $\delta^{18} \mathrm{O}$ gradients during JFM ranging from -1.14 to $0.68 \% / 10^{\circ}$. The isotopic balance model applied to the Amazon basin (Dall'Olio 1976) yields steeper negative gradients during DJF $\left(-2.3 \% / 10^{\circ}\right)$. All models display an abnormal continental gradient during JJA. The gradient vanishes for $\mathrm{REMO}_{\text {iso }}$ and even becomes positive for ECHAM T106 and T30. Salati et al. show a large scatter of $\delta^{18} \mathrm{O}$ during JJA, showing no distinct continental gradient. Similarly, the isotopic balance model shows an initial depletion of $\delta^{18} \mathrm{O}$ by $1 \%$ between $45^{\circ}$ and $60^{\circ} \mathrm{W}$, followed by a reenrichment of the same amplitude at $70^{\circ} \mathrm{W}$. Vuille et al. (2003a) reports a vanishing of the $\delta^{18} \mathrm{O}$ continental gradient across the Amazon in the GISS-II isotope-enabled GCM. Furthermore, the mean $\delta^{18} \mathrm{O}$ is overestimated in all models, as compared to GNIP. Precipitation in ECHAM is underestimated during JJA, but $\mathrm{REMO}_{\text {iso }}$ is in good agreement with the WML dataset.

The present modeling results reinforce the role of transpiration on the weakening of the $\delta^{18} \mathrm{O}$ continental gradient. During the dry season, precipitation is weak, hence the depletion mechanism is diminished. Water uptake by plants, which is still strong during the dry season, is released to the atmosphere without fractionation. Hence, continuous recycling of moisture by vegetation progressively counterbalances, and locally overcomes, the continental rainout. The latter results in a cancelling of the $\delta^{18} \mathrm{O}$ continental gradient.
The effect of recycling is enhanced in the models since all vapor fluxes from the surface are considered nonfractionating (i.e., depleted evaporation from bare soils and open water bodies such as ponds and rivers is neglected). This contributes to the overestimation of $\delta^{18} \mathrm{O}$ during JJA. When the latter combines with underestimated precipitation (hence reduced amount effect), as in ECHAM T106, the continental gradient is reversed and becomes positive. As further evidence, the modeled deuterium excess (not shown) has a negative bias at Manaus, reflecting the lack of kinetic fractionation over land.

In conclusion, the discrepancies in the simulated $\delta^{18} \mathrm{O}$ continental gradient across the Amazon basin underline the need of a better representation of landatmospheric moisture fluxes in circulation models. Nevertheless, these results confirm the potential use of stable water isotopes as a proxy for moisture recycling by vegetation. Henderson-Sellers et al. (2002) provide a detailed investigation of that topic.

\section{c. Evolution of the isotopic composition of moisture along its trajectory}

Only a fraction of the $\delta^{18} \mathrm{O}$ variability is explained by the amount effect, that is, local regression of $\delta^{18} \mathrm{O}$ versus precipitation: the squared correlation coefficient $\left(r^{2}\right)$ of monthly $\delta^{18} \mathrm{O}$ with precipitation for $\mathrm{REMO}_{\text {iso }}$, ECHAM T106, and ECHAM T30 is, respectively, equal to $23 \%, 32 \%$, and $39 \%$. This underlines the integrative character of the isotopic signal. It is hence more appropriate to look at the fractionation processes in a Lagragian (i.e., following an air parcel) instead of the traditional Eulerian (i.e., station location) reference frame. Monthly wind fields from $\mathrm{REMO}_{\text {iso }}$ were used to compute the streamline that reaches Pôrto Velho $\left(9.5^{\circ} \mathrm{S}, 65.5^{\circ} \mathrm{W}\right)$ and Ceara Minim $\left(3.5^{\circ} \mathrm{S}, 37.5^{\circ} \mathrm{W}\right)$. We make the assumption that streamlines represent the monthly standard back-trajectories. This is justified only if the upstream wind fields are close to stationary. To test it, we computed the wind directional constancy on 6-hourly wind fields [Eq. (2) $]^{4}$. In case of steady winds, $D_{c}=1$, whereas it decreases toward 0 if its direction is very variable. In the present case, $D_{c}>0.8$ over tropical South America. Furthermore, the computed streamlines agree well with back-trajectories computed with 6-h NCEP reanalyses for each calendar month (Vimeux et al. 2005). Based on ERA-40 reanaly-

\footnotetext{
${ }^{4}$ Definition of the wind directional constancy:

$$
D_{c}=\frac{\|\overline{\mathbf{H}}\|}{\| \overline{\mathbf{H} \|}}=\frac{\sqrt{{\overline{H_{u}}}^{2}+{\overline{H_{\nu}}}^{2}}}{\sqrt{{H_{u}^{2}+H_{\nu}^{2}}^{2}}} .
$$
}




\section{Ceara Minim}

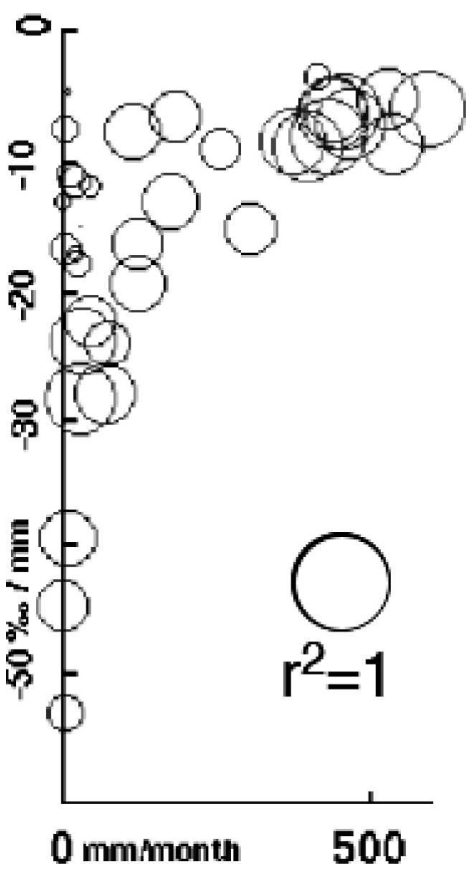

FIG. 10. Total monthly precipitation along trajectories reaching the coastal station Ceara Minim $\left(3.5^{\circ} \mathrm{S}, 37.5^{\circ} \mathrm{W}\right)$ is plotted on the $x$ axis $\left(\mathrm{mm}\right.$ month $\left.^{-1}\right)$, and the amount effect coefficient $\left(\partial \delta^{18} \mathrm{O} / \partial P\right.$ along the trajectory) on the $y$ axis (in $\%{ }^{\circ} \mathrm{m}^{-1}$ ). The circle size is proportional to the squared correlation coefficient $r^{2}$.

ses, Rao et al. (1996) report that vapor transport by transient eddies is negligible north of $30^{\circ} \mathrm{S}\left(20^{\circ} \mathrm{S}\right)$ during DJF (JJA). Hence mean motion is the dominant vapor advection in tropical South America. All three arguments demonstrate that the assumption above is valid. In the following, trajectories are assimilated to the corresponding streamlines.

A regression of monthly $\delta^{18} \mathrm{O}$ against precipitation along the mean monthly trajectory is shown in Fig. 10. The variation of the amount effect $\left(\mathrm{AE}=\partial \delta^{18} \mathrm{O} / \partial P\right.$, in $\% \mathrm{~m}^{-1}$ ) displays a hyperbolic shape, as expected for Rayleigh distillation processes. During the dry season, the relative degree of distillation is high: even small precipitation events can deplete significantly the cloud vapor. Hence the $\mathrm{AE}$ reaches down to $-50 \% \mathrm{~m}^{-1}$. During the wet season, AE stabilizes at $-7 \% \mathrm{~m}^{-1}$. Furthermore, the increased correlation coefficient proves that precipitation amounts control the $\delta^{18} \mathrm{O}$ signal more during the wet than the dry season, where other processes such as evapotranspiration become dominant. The weighted mean value of AE in Fig. 10, calculated in the Lagrangian reference frame, is in good agreement with $\overline{\partial \delta^{18} \mathrm{O} / \partial P}=-9.17 \% \mathrm{~m}^{-1}$ calculated using the Eulerian referential. Similar slopes are reported for
ECHAM T106/ ECHAM T30/ GNIP, respectively: $\overline{\partial \delta^{18} \mathrm{O} / \partial P}=-10.7 /-11.5 /-9.23 \% \mathrm{~m}^{-1}$.

We investigate the processes responsible for isotopic fractionation by considering the joint evolution of $\delta^{18} \mathrm{O}$ and precipitation along their trajectory (Fig. 11). Albeit the significant interannual variability of back-trajectories, the $\mathrm{AE}$ is fairly constant at $-6 \% \mathrm{~m}^{-1}$ with $r^{2}$ reaching up to $72 \%$. The continental rainout is well described by the assumption of a Rayleigh distillation, with condensate (rain) being instantly removed from the reservoir (cloud vapor) without major further inputs (evaporation). Salati et al. (1979) also reports Rayleigh-type distillation processes across the Amazon basin (from Amapá over Manaus to Pôrto Velho) in JFM, where moisture recycling by the vegetation is negligible because of high relative humidity. It further indicates that the positive $\delta^{18} \mathrm{O} /$ longitude gradient in DJF for $\mathrm{REMO}_{\text {iso }}$ (cf. Table 3) is an artifact due to the projection of the trajectory on the $x$ axis.

Figure 12 displays the analogous situation for July, during the dry season. Hardly any precipitation occurs along the trajectory (apart from some orographic precipitation upon reaching the foothills and lowering there the $\delta^{18} \mathrm{O}$ ). Large variations in $\delta^{18} \mathrm{O}$ occur, with a positive trend over the continent, reaching positive values. Salati et al. (1979) reports the vanishing of the continental effect during JJA. A simple isotopic model taking into account reevaporation effects locally produces positive continental gradients (Dall'Olio 1976). This further reinforces the positive $\delta^{18} \mathrm{O} /$ longitude gradient reported in Table 3. During the dry season, precipitation amounts no longer control the isotopic signal. The $\delta^{18} \mathrm{O}$ is determined by the isotopic equilibrium at the surface. Nonfractionating transpiration by the vegetation, which remains significant throughout the dry season, releases nondepleted soil water into the atmosphere. The partial reequilibration of falling rain droplets with surrounding (too enriched) vapor explains the anomalous high $\delta^{18} \mathrm{O}$ values in the heart of the Amazon. This discrepancy is further enhanced in $\mathrm{REMO}_{\text {iso }}$ ECHAM since all evaporation from the surface is considered nonfractionating.

In conclusion, this study confirms the use of stable water isotope diagnostics for understanding the water cycle in the Amazon. Precipitation $\delta^{18} \mathrm{O}$ records Rayleigh distillation processes in convective clouds, as well as the partition between evaporation and transpiration at the surface. Such characteristics can be applied, for example, to estimate the recycling rate of precipitation over the Amazon and further assess the impact of deforestation on the water cycle (Henderson-Sellers et al. 2002). 

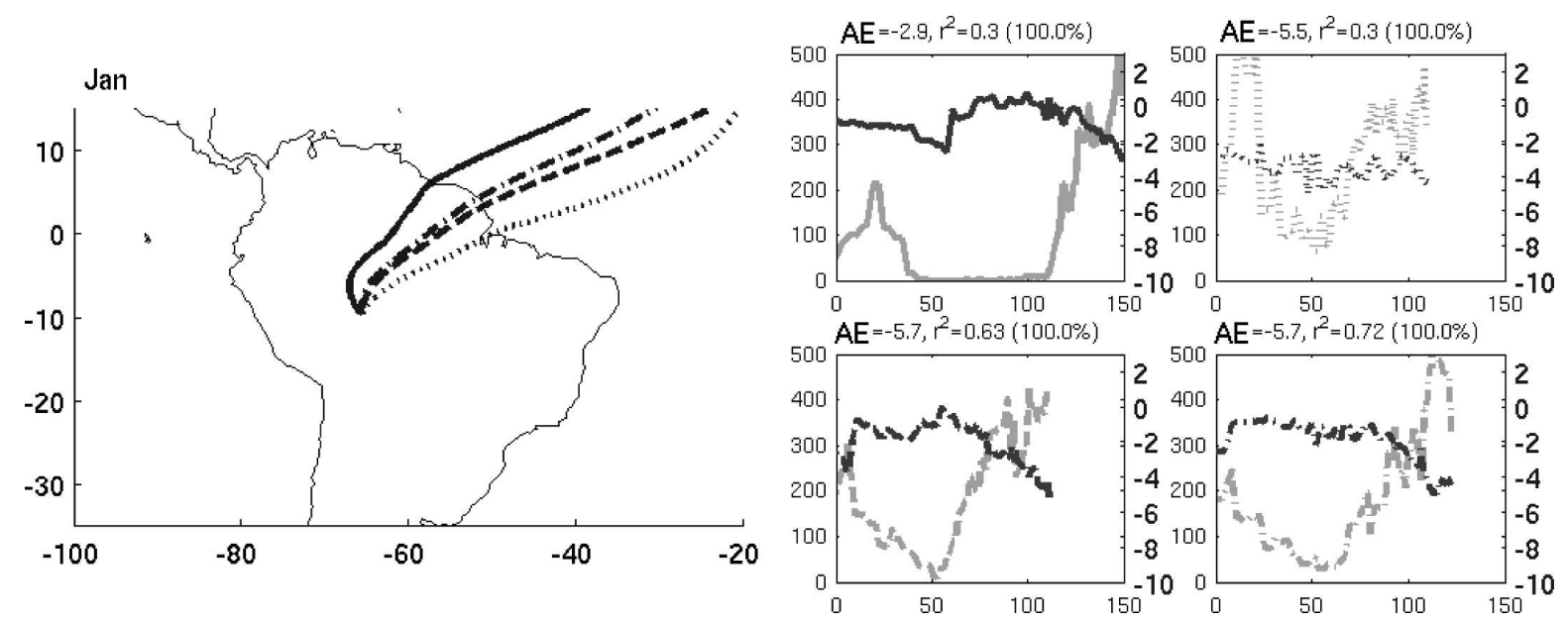

FIG. 11. (left) Back-trajectories from Pôrto Velho $\left(9.5^{\circ} \mathrm{S}, 65.5^{\circ} \mathrm{W}\right)$ in January (years 2 to 5). (right) The evolution of $\delta^{18} \mathrm{O}$ (in $\%$; dark gray; $y$ axis on the right) and precipitation ( $\mathrm{mm}$ month $^{-1}$; light gray; $y$ axis on the left) along the trajectory $(x$ axis; h) for each year. The AE $\left(\% \mathrm{~m}^{-1}\right)$ is indicated for each case, as well as the squared regression coefficient $r^{2}$, and its significance.

\section{Conclusions and perspectives}

The present study introduces a simulation of the stable water isotope signal by the regional circulation model $\mathrm{REMO}_{\text {iso }}$ over tropical South America. The numerical integration is conducted at a horizontal resolution of $0.5^{\circ}(\sim 53 \mathrm{~km})$ over a 5-yr period, forced with climatological sea surface temperature (SST).

The simulated precipitation patterns and their seasonal variability are in reasonable agreement with interpolated rain gauge and satellite observations. $\mathrm{REMO}_{\text {iso }}$ overestimates precipitation by $30 \%$ all yearround but reproduces correctly the distribution of rainfall over the continent. Since precipitation is mostly convective, we believe that overestimation of precipitation by $\mathrm{REMO}_{\text {iso }}$ could be corrected if we tune
$\mathrm{REMO}_{\text {iso }}$ 's convection scheme to tropical settings, according to Aldrian et al. (2004). Both ECHAM simulations underestimate precipitation during the dry season (JJA). The major discrepancy between models and observations happens during MAM. REMO ${ }_{\text {iso }}$ and ECHAM have in common exaggerated precipitation over the ocean (in connection with the intertropical convergence zone). Unlike observations, the models locate the maximum of precipitation on the east slope of the Andes instead of the Amazon delta.

Furthermore, typical meteorological features of the South American $\delta^{18} \mathrm{O}$ climatology are well represented in $\mathrm{REMO}_{\text {iso }}$. During DJF, the mean sea level pressures denote a thermal low at $25^{\circ} \mathrm{S}, 60^{\circ} \mathrm{W}$ (Chaco low), in agreement with the ERA-40 reanalyses. Vertically integrated moisture transport shows an important advec-
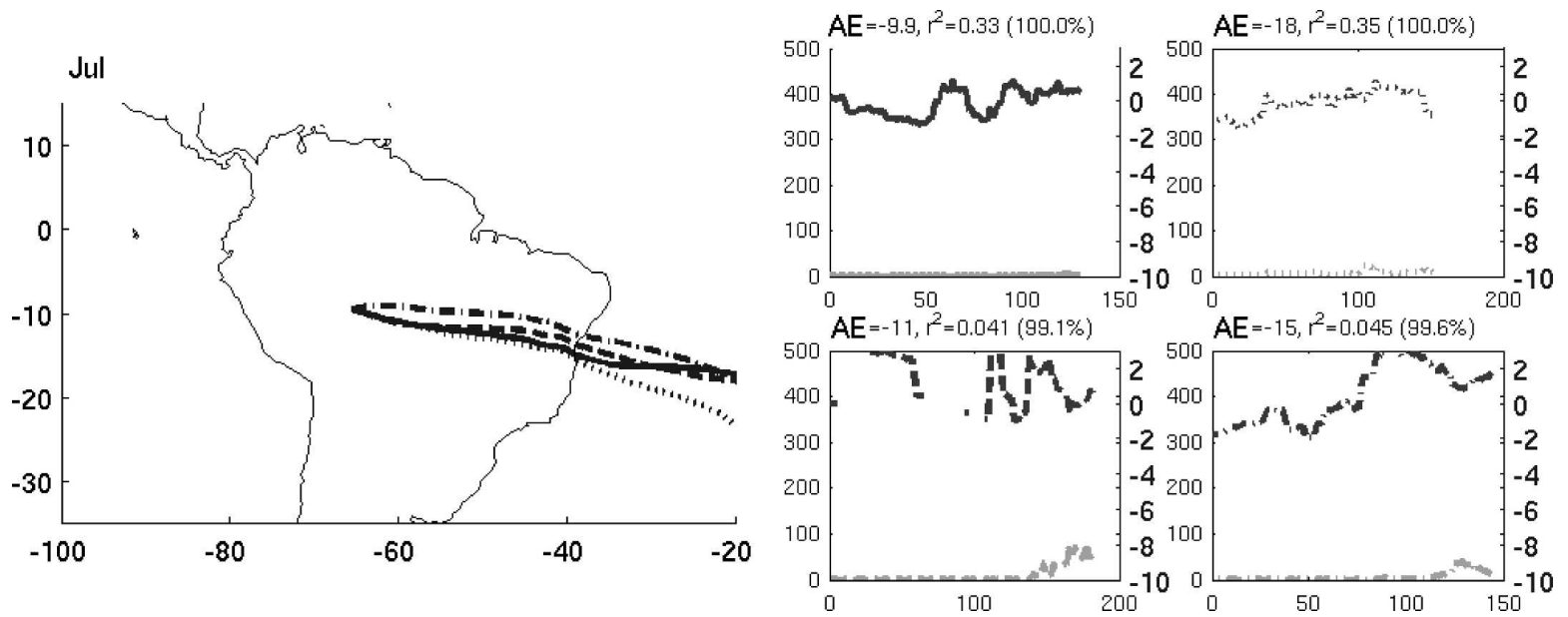

FIG. 12. As in Fig. 11 but for July. 
tion across the Amazon basin, diverted by the Andean Cordillera to a northwest-southeast flow toward the Paraná region. Latent heat release by convection over the Amazon basin cause a 4-K warm anomaly at 300 $\mathrm{hPa}$. The latter is responsible for a local maximum of geopotential at $200 \mathrm{hPa}$ around $19^{\circ} \mathrm{S}, 63^{\circ} \mathrm{W}$ (Bolivian high). The 200-hPa convergence field indicates, besides the intertropical convergence zone (ITCZ), the subtropical south Atlantic convergence zone (SACZ) at $30^{\circ} \mathrm{S}, 35^{\circ} \mathrm{W}$. The increased resolution in $\mathrm{REMO}_{\text {iso }}$ significantly improves the atmospheric circulation and meteorological patterns along the Andean Cordillera.

The simulated $\delta^{18} \mathrm{O}$ signal in precipitation is in fair agreement with isotopic observations (GNIP climatology), as well as coarser-resolution general circulation models $\left(\right.$ ECHAM $_{\text {iso }}$ T106 and T30), both on an annual and seasonal basis. The three models are compared to GNIP station measurements in $5^{\circ} \times 5^{\circ}$ boxes, located at the coast (Cayenne), in the Amazon basin (Manaus), and at the foothills of the Andes (Pôrto Velho). The simulated isotopic composition is close to observations at the coast but is overestimated (particularly during the dry season) over the Amazon basin. At Pôrto Velho, precipitation adopts a single maximum distribution typical of the outer Tropics, but the $\delta^{18} \mathrm{O}$ signal inherits the upstream double maxima shape. This underlines the integrative character of the water isotope proxy. $\mathrm{REMO}_{\text {iso }}$ and ECHAM T30/T106 have the same physical parameterization of fractionation processes; hence their results are qualitatively equivalent. The higher resolution in $\mathrm{REMO}_{\text {iso }}$ simulates more accurate back-trajectories, which leads to a better agreement with observations due to the integrative character of the isotopic signal.

Simulated mean annual $\delta^{18} \mathrm{O}$ is anticorrelated with altitude for $\mathrm{REMO}_{\text {iso }}$ and $\mathrm{ECHAM}_{\text {iso }}$ T106. A linear regression of $\delta^{18} \mathrm{O}$ against altitude reveals that altitude is an important control of the $\delta^{18} \mathrm{O}$ distribution for all seasons. This reinforces the need of high-resolution topography when modeling the isotopic signal in the Andes. The simulated $\delta^{18} \mathrm{O}$ altitude gradient $\left(\Delta \delta^{18} \mathrm{O} / \Delta z=\right.$ $-1.7 \% / 100 \mathrm{~m}$ ) matches reported observed gradients in literature. Only $\mathrm{REMO}_{\text {iso }}$ is able to capture the increase of the altitude gradient with height (positive second derivative of $\delta^{18} \mathrm{O}$ with altitude). The similarity between the $\delta^{18} \mathrm{O}$ altitude curve of $\mathrm{REMO}_{\text {iso }}$ highaltitude grid cells and the curve derived from the Rayleigh distillation theory suggests that $\mathrm{REMO}_{\text {iso }}$ reproduces the lifting of moisture along the Andean slopes mainly as a distillation process. Teledetection and in situ measurements both indicate that a pure Rayleigh distillation rather represents a lower limit for real water isotope gradients (Schmidt et al. 2005). The deviation from this theoretical lower limit increases to $100 \%$ near the tropopause. Numerous processes have been suggested such as mixing, ice crystal lofting, bypassing the Rayleigh distillation, etc., to explain this divergence. A steep orographic obstacle such as the Andes adds to the complexity of processes contributing to vertical isotope gradients, which will be an important objective for further studies. Furthermore, the present study concentrates on the model's sensitivity to horizontal resolution; hence, $\mathrm{ECHAM}_{\text {iso }}$ and $\mathrm{REMO}_{\text {iso }}$ were run on the same 19 vertical levels. It is nevertheless arguable that a consistent high-resolution simulation by $\mathrm{REMO}_{\text {iso }}$ would require an increased vertical resolution. An extensive discussion of these points is beyond the scope of the present study and will be addressed in a future publication. In conclusion, these preliminary results are encouraging, considering the ultimate objective of interpreting the regional significance of the isotopic signal in Andean tropical ice cores with $\mathrm{REMO}_{\text {iso. }}$ Besides the points previously mentioned, further downscaling techniques for isotopic diagnostics need to be developed in order to compare simulation results with field campaigns.

The analysis of simulated $\delta^{18} \mathrm{O}$ transects across the Amazon basin reveals that the continental gradient is much weaker there than in midlatitudes. This underlines the importance of moisture recycling by vegetation, especially during the dry season when the evapotranspiration flux exceeds moisture advection from outside the Amazon basin. Given the simple representation of surface hydrology, evapotranspiration is parameterized in the models as a nonfractionating water transfer, which therefore overestimates the atmospheric and precipitation $\delta^{18} \mathrm{O}$. As a consequence, the continental gradient vanishes in $\mathrm{REMO}_{\text {iso }}$ and even becomes positive in ECHAM T106.

Seasonal maps, as well as box averages, reinforce the integrative character of $\delta^{18} \mathrm{O}$ : the isotopic signal in the Tropics is a proxy of cumulated precipitation along the trajectory rather than local precipitation. To assess the latter, we identify the common evolution of precipitation and $\delta^{18} \mathrm{O}$ along the parcel trajectory. This Lagrangian analysis yields a similar regression slope $\partial \delta^{18} \mathrm{O} / \partial P=$ $-9.17 \% \mathrm{~m}^{-1}$ as the regression in the Eulerian referential, but with much higher regression coefficients $\left(r^{2}>\right.$ $50 \%$ ) during the rainy season. The evolution along the dry season trajectory confirms that evapotranspiration rather than precipitation controls the $\delta^{18} \mathrm{O}$. This new Lagrangian approach bridges the gap between the Eulerian analysis of distributed regional/global circulation models and trajectory-based, Rayleigh-type distillation models.

The present study has focused on the mean (clima- 

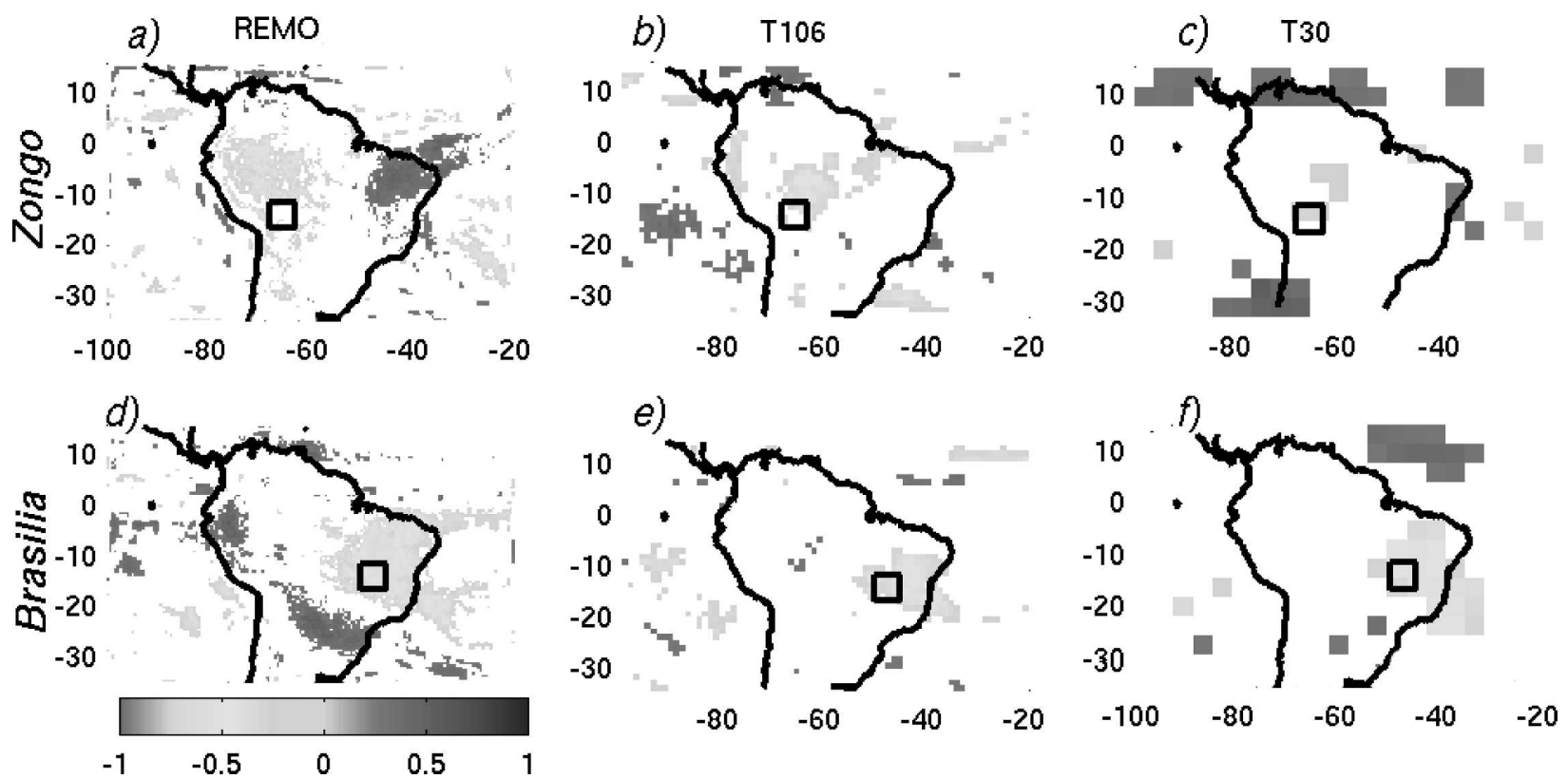

FIG. 13. Correlation between $\delta^{18} \mathrm{O}$ anomalies averaged over a $5^{\circ} \times 5^{\circ}$ box and domainwide precipitation. (top) The average $\delta^{18} \mathrm{O}$ is computed at the Zongo box, centered at $4.5^{\circ} \mathrm{S}, 64.5^{\circ} \mathrm{W}$. (bottom) The average $\delta^{18} \mathrm{O}$ is computed over the Brasilia box $\left(14.5^{\circ} \mathrm{S}, 47.5^{\circ} \mathrm{W}\right)$.

tological) distribution of $\delta^{18} \mathrm{O}$, where the higher resolution improves the simulation of local processes. Hence, variability of $\delta^{18} \mathrm{O}$ on steep relief is better resolved in $\mathrm{REMO}_{\text {iso, }}$, while it remained mostly out of reach to ECHAM. The benefits of higher resolution is obvious when looking at other local phenomena, such as the low-level jets along the east slope of the central Andes. Figure 13 shows the correlation of monthly anomalies (from the climatological mean) between the $\delta^{18} \mathrm{O}$ at the foothills of the Andes and the domainwide reveals a dipole shape in $\mathrm{REMO}_{\text {iso }}$. This feature remains largely absent in the coarser ECHAM iso $_{\text {simula- }}$ tions. The dipole structure is related to the variability of the South American monsoon system. A detailed investigation of the latter is given in a separate study (Sturm et al. 2007).

In conclusion, the present study not only validates the $\mathrm{REMO}_{\text {iso }}$ regional circulation model over South America, but also underlines the benefit of increased resolution for the interpretation of the stable isotopic signal. $\mathrm{REMO}_{\text {iso }}$ is an appropriate tool to contribute to the interpretation of present isotopic archives (ice cores, speleothems, and isotopic dendrochronology). Further nesting of $\mathrm{REMO}_{\text {iso }}$ in paleo simulations by $\mathrm{ECHAM}_{\text {iso }}$ could assess the regional significance of isotopic archives.

Acknowledgments. The authors thank Martin Werner (Max-Planck-Institute for Biogeochemistry, Jena) for providing the $\mathrm{ECHAM}_{\text {iso }}$ T106 simulation. Further- more, the valuable comments by Françoise Vimeux (Institut de Recherche pour le Développement) and Gerhard Krinner (Laboratoire de Glaciologie et Géophysique de l'Environnement) contributed significantly to the quality of the manuscript. All numerical integrations of $\mathrm{REMO}_{\text {iso }}$ and $\mathrm{ECHAM}_{\text {iso }}$ were performed on the German Climate Computing Centre (DKRZ, Hamburg). Model development was supported by the French science foundation (ACI-Cryosphere and Climate Change) and by the European project ALP-IMP (BBW 01.0498-1).

\section{REFERENCES}

Aldrian, E., L. Dümenil-Gates, D. Jacob, R. Podzun, and D. Gunawan, 2004: Long-term simulation of Indonesian rainfall with the MPI regional model. Climate Dyn., 22, 795-814.

Bradley, R. S., M. Vuille, D. Hardy, and L. G. Thompson, 2003: Low latitude ice cores record Pacific sea surface temperatures. Geophys. Res. Lett., 30, 1174, doi:10.1029/2002GL016546.

Chou, S. C., A. M. B. Nunes, and I. F. A. Cavalcanti, 2000: Extended range forecasts over South America using the regional eta model. J. Geophys. Res., 105, 10 147-10 160.

Costa, M. H., and J. A. Foley, 1998: A comparison of precipitation datasets for the Amazon basin. Geophys. Res. Lett., 25, 155158.

Dall'Olio, A., 1976: A composicão isotopica das precipitacãos do Brasil: Modelos isotermicos e a influencia da evapotranspiracão na Basina Amazonica. M.S. thesis, Dept. of Meteorology, University of São Paulo, 180 pp.

Dansgaard, W., 1964: Stable isotopes in precipitation. Tellus, 16, 436-468.

Doherty, R., M. Hulme, and C. Jones, 1999: A gridded recon- 
struction of land and ocean precipitation for the extended tropics from 1974 to 1994. Int. J. Climatol., 19, 119-142.

ECMWF, cited 2003: ECMWF 40 Years Re-Analysis, monthly means. [Available online at http://data.ecmwf.int/data/d/ era40_mnth/.]

Ginot, P., M. Schwikowski, U. Schotterer, W. Stichler, H. W. Gäggeler, B. Francou, R. Gallaire, and B. Pouyaud, 2002: Potential for climate variability reconstruction from Andean glaciochemical records. Ann. Glaciol., 35, 443-450.

Gonfiantini, R., M. Roche, J. Olivry, J. Fontes, and G. Zuppi, 2001: The altitude effect on the isotopic composition of tropical rains. Chem. Geol., 181, 147-167.

Hastenrath, S., 1997: Annual cycle of upper air circulation and convective activity over the tropical Americas. J. Geophys. Res., 102, 4267-4274.

Henderson-Sellers, A., K. McGuffie, and H. Zhang, 2002: Stable isotopes as validation tools for global climate model predictions of the impact of Amazonian deforestation. J. Climate, 15, 2664-2677.

Hoffmann, G., 2003: Taking the pulse of the tropical water cycle. Science, 301, 776-777.

- M. Werner, and M. Heimann, 1998: Water isotope module of the ECHAM atmospheric general circulation model: A study on timescales from days to several years. J. Geophys. Res., 103, 16 871-16 896.

- and Coauthors, 2003: Coherent isotope history of Andean ice cores over the last century. Geophys. Res. Lett., 30, 1179, doi:10.1029/2002GL014870.

Huffman, G., and D. Bolvin, cited 2004: GPCP version 2 combined precipitation data set. [Available online at http://www. ncdc.noaa.gov/oa/wmo/wdcamet-ncdc.html\#version2.]

Hulme, M., T. J. Osborn, and T. C. Johns, 1998: Precipitation sensitivity to global warming: Comparison of observations with HadCM2 simulations. Geophys. Res. Lett., 25, 3379-3382.

IAEA and WMO, cited 2001: The Global Network of Isotopes in Precipitation (GNIP) database. [Available online at http:// isohis.iaea.org.]

Lai, C.-T., J. R. Ehleringer, B. J. Bond, and K. T. Paw U, 2006: Contributions of evaporation, isotopic non-steady state transpiration and atmospheric mixing on the $\delta^{18} \mathrm{O}$ of water vapour in Pacific Northwest coniferous forests. Plant Cell Environ., 29, 77-94.

Lenters, J. D., and K. H. Cook, 1995: Simulation and diagnosis of the regional summertime precipitation climatology of South America. J. Climate, 8, 2988-3005.

_, and _ 1997: On the origin of the Bolivian high and related circulation features of the South American climate. $J$. Atmos. Sci., 54, 656-678.

— , and — 1999: Summertime precipitation variability in South America: Role of the large-scale circulation. Mon. Wea. Rev., 127, 409-431.

Merlivat, L., and J. Jouzel, 1979: Global climatic interpretation of the deuterium-oxygen 18 relationship for precipitation. $J$. Geophys. Res., 84, 5029-5033.

Nordeng, T., 1994: Extended versions of the convective parameterization scheme at ECMWF and then-impact on the mean and transient activity of the model in the tropics. ECMWF Tech. Memo. 206, 7 pp.

Ramirez, E., and Coauthors, 2003: A new Andean deep ice core from Nevado Illimani $(6350 \mathrm{~m})$, Bolivia. Earth Planet. Sci. Lett., 212, 337-350.
Rao, V. B., I. F. A. Cavalcanti, and K. Hada, 1996: Annual variation of rainfall over Brazil and water vapor characteristics over South America. J. Geophys. Res., 101, 26 539-26 552.

Rayner, N. A., E. B. Horton, D. E. Parker, C. K. Folland, and R. B. Hackett, 1996: Version 2.2 of the Global Sea-Ice and Sea Surface Temperature Data Set, 1903-1994. Climate Research Tech. Note 74, Hadley Centre for Climate Prediction and Research, $50 \mathrm{pp}$. [Available online at http://hadobs. metoffice.com/gisst/crtn74.pdf.]

Roche, M., R. Gonfiantini, J. Fontes, N. Abasto, and L. Noriega, 1999: The isotopic composition of precipitation on the Andes and Amazon of Bolivia. Extended Abstracts, Int. Symp. on Isotopes in Hydrology, Vienna, Austria, International Atomic Energy Agency, 1-10.

Rojas, M., and A. Seth, 2003: Simulation and sensitivity in a nested modeling system for South America. Part II: GCM boundary forcing. J. Climate, 16, 2454-2471.

Salati, E., A. Dall'Olio, E. Matsui, and J. Gat, 1979: Recycling of water in the Amazon basin: An isotopic study. Water Resour. Res., 15, 1250-1257.

Schmidt, G. A., G. Hoffmann, D. T. Shindell, and Y. Hu, 2005: Modeling atmospheric stable water isotopes and the potential for constraining cloud processes and stratosphere-troposphere water exchange. J. Geophys. Res., 110, D21314, doi:10.1029/2005JD005790.

Seth, A., and M. Rojas, 2003: Simulation and sensitivity in a nested modeling system for South America. Part I: Reanalyses boundary forcing. J. Climate, 16, 2437-2453.

Siegenthaler, U., and H. Oeschger, 1980: Correlation of ${ }^{18} \mathrm{O}$ in precipitation with temperature and altitude. Nature, 285, 314-317.

Sturm, K., G. Hoffmann, B. Langmann, and W. Stichler, 2005: Simulation of $\delta^{18} \mathrm{O}$ in precipitation by the regional circulation

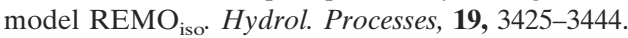

_, F. Vimeux, and G. Krinner, 2007: The South American monsoon recorded in stable water isotopes. J. Geophys. Res., in press.

Thompson, L. G., E. Mosley-Thompson, and K. A. Henderson, 2000: Ice-core palaeoclimate records in tropical South America since the Last Gacial Maximum. J. Quat. Sci., 15, 377-394.

Vera, C., 2004: Introduction to the South American Low-Level Jet Experiment (SALLJEX). CLIVAR Exchanges, Vol. 9, No. 1, International CLIVAR Project Office, Southampton, United Kingdom, 3-4.

Vernekar, A. D., B. P. Kirtman, and M. J. Fennessy, 2003: Lowlevel jets and their effects on the South American summer climate as simulated by the NCEP Eta Model. J. Climate, 16, 297-311.

Vimeux, F., R. Gallaire, S. Bony, G. Hoffmann, and J. C. H. Chiang, 2005: What are the controls on $\delta \mathrm{D}$ in precipitation in the Zongo Valley (Bolivia)? Implications for the Illimani ice core interpretation. Earth Planet. Sci. Lett., 240, 205-220.

Vogel, J., J. Lerman, and W. Mook, 1975: Natural isotopes in surface and groundwater from Argentina. Hydrol. Sci. Bull., 20, 203-221.

von Storch, H., H. Langenberg, and F. Feser, 2000: A spectral nudging technique for dynamical downscaling purposes. Mon. Wea. Rev., 128, 3664-3673.

Vuille, M., R. S. Bradley, M. Werner, R. Healy, and F. Keimig, 
2003a: Modeling $\delta^{18} \mathrm{O}$ in precipitation over the tropical Americas: 1 . Interannual variability and climatic controls. $J$. Geophys. Res., 108, 4174, doi:10.1029/2001JD002038.

, R. Healy, M. Werner, D. R. Hardy, L. G. Thompson, and F. Keimig, 2003b: Modeling $\delta^{18} \mathrm{O}$ in precipitation over the tropical Americas: 2. Simulation of the stable isotope signal in Andean ice cores. J. Geophys. Res., 108, 4175, doi:10.1029/2001JD002039.

Werner, M., U. Mikolajewicz, M. Heimann, and G. Hoffmann,
2000: Borehole versus isotope temperatures on Greenland: Seasonality does matter. Geophys. Res. Lett., 27, 723-726.

Willmott, C., and K. Matsuura, cited 2001: Terrestrial air temperature and precipitation: Monthly and annual time series (1950-1999). [Available online at http://climate.geog.udel. edu/ climate/html_pages/README.ghcn_ts2.html.]

Xie, P., and P. Arkin, cited 2002: CPC Merged Analysis of Precipitation (CMAP). [Available online at http://www.cgd.ucar. edu/cas/catalog/surface/precip/arkin.html.] 
Copyright of Journal of Climate is the property of American Meteorological Society and its content may not be copied or emailed to multiple sites or posted to a listserv without the copyright holder's express written permission. However, users may print, download, or email articles for individual use. 